\title{
Sphenopalatine ganglion: block, radiofrequency ablation and neurostimulation - a systematic review
}

\author{
Kwo Wei David Ho ${ }^{1 *}$, Rene Przkora ${ }^{2}$ and Sanjeev Kumar ${ }^{2}$
}

\begin{abstract}
Background: Sphenopalatine ganglion is the largest collection of neurons in the calvarium outside of the brain. Over the past century, it has been a target for interventional treatment of head and facial pain due to its ease of access. Block, radiofrequency ablation, and neurostimulation have all been applied to treat a myriad of painful syndromes. Despite the routine use of these interventions, the literature supporting their use has not been systematically summarized. This systematic review aims to collect and summarize the level of evidence supporting the use of sphenopalatine ganglion block, radiofrequency ablation and neurostimulation.

Methods: Medline, Google Scholar, and the Cochrane Central Register of Controlled Trials (CENTRAL) databases were reviewed for studies on sphenopalatine ganglion block, radiofrequency ablation and neurostimulation. Studies included in this review were compiled and analyzed for their treated medical conditions, study design, outcomes and procedural details. Studies were graded using Oxford Center for Evidence-Based Medicine for level of evidence. Based on the level of evidence, grades of recommendations are provided for each intervention and its associated medical conditions.
\end{abstract}

Results: Eighty-three publications were included in this review, of which 60 were studies on sphenopalatine ganglion block, 15 were on radiofrequency ablation, and 8 were on neurostimulation. Of all the studies, 23 have evidence level above case series. Of the 23 studies, 19 were on sphenopalatine ganglion block, 1 study on radiofrequency ablation, and 3 studies on neurostimulation. The rest of the available literature was case reports and case series. The strongest evidence lies in using sphenopalatine ganglion block, radiofrequency ablation and neurostimulation for cluster headache. Sphenopalatine ganglion block also has evidence in treating trigeminal neuralgia, migraines, reducing the needs of analgesics after endoscopic sinus surgery and reducing pain associated with nasal packing removal after nasal operations.

Conclusions: Overall, sphenopalatine ganglion is a promising target for treating cluster headache using blocks, radiofrequency ablation and neurostimulation. Sphenopalatine ganglion block also has some evidence supporting its use in a few other conditions. However, most of the controlled studies were small and without replications. Further controlled studies are warranted to replicate and expand on these previous findings.

Keywords: Sphenopalatine ganglion, Block, Radiofrequency ablation, Neurostimulation, Nerve stimulation, Neuromodulation

\footnotetext{
* Correspondence: KwoWei.Ho@neurology.ufl.edu

${ }^{1}$ Department of Neurology, University of Florida, PO Box 100236,1149 Newell

Drive, Room L3-100, Gainesville, FL 32611, USA

Full list of author information is available at the end of the article
} 


\section{Review}

The sphenopalatine ganglion (SPG) is also known as pterygopalatine ganglion, nasal ganglion or Meckel's ganglion. It is the largest and most superior ganglion of sensory, sympathetic and parasympathetic nervous system. It has the largest collection of neurons in the calvarium outside of the brain. It is also the only ganglion having access to the outside environment through the nasal mucosa. SPG gives rise to greater and lesser palatine nerves, nasopalatine nerve, superior, inferior and posterior lateral nasal branches, as well as the pharyngeal branch of the maxillary nerve. There are also orbital branches reaching the lacrimal gland.

Because of its proximity to multiple important neuroanatomic structures in pain perception, SPG has been postulated to be involved in facial pain and headaches for over a century. For headache, SPG is thought to play a central role in the generation of trigeminal autonomic cephalalgia (TAC). TAC is a broad term that encompasses cluster headache, paroxysmal hemicrania, and short-lasting unilateral neuralgiform headache attack with conjunctival injection and tearing (SUNCT). It is typically distributed in the trigeminal distribution with ipsilateral cranial autonomic features. TAC is characterized by parasympathetic (lacrimation, rhinorrhea, nasal congestion and edema) activation and sympathetic dysfunction (ptosis and miosis). These clinical features can be explained by the activation of the sympathetic and parasympathetic pathways within SPG [1]. The disruption of this pathway by SPG blockade is thought to be central to relieving the headache produced by TAC. For face and neck neuralgias, connections of SPG with facial nerve, lesser occipital nerve and cutaneous cervical nerves are thought to be the mechanism [1]. Irritation of the SPG can also cause orbital, periorbital and mandibular symptoms through its connection with the ciliary and otic ganglions and reflex otalgia by its connection with the tympanic plexus. Connections of SPG with the vagus nerve may produce visceral symptoms in dysfunctional states [1]. SPG may also play an important role in vasodilation to protect the brain against ischemia from stroke or migraine with aura. This mechanism is thought to be through the postganglionic parasympathetic fibers, which are connected to the vascular beds of the cerebral hemisphere [2]. Because the upper cervical roots are connected to the superior cervical ganglion through the sympathetic trunk, which is connected to the deep petrosal nerve then to the SPG, SPG blockade is thought to be able to relieve pain from the head, face, neck and upper back [1]. This is the rationale for using SPG block in treating any head, face, neck pain refractory to conventional treatment. Through the inhibition of the sympathetic trunk, SPG block was also thought to be useful in treating generalized muscle pain including fibromyalgia and low back pain [3]. For postdural puncture headache, the pain mechanism is thought to be secondary to cerebrospinal fluid leak that exceeds the production rate, causing traction on the meninges and parasympathetic mediated reflex vasodilatation of the meningeal vessels. SPG blockade is thought to work through blocking the parasympathetic flow to the cerebral vasculature, allowing the cerebral vessels to return to normal diameter, thus relieving the headache [4].

Although the mechanism by which pain is produced from SPG is not well-characterized, SPG has been the treatment target ranging from cluster headache to low back pain. Three main types of interventions are currently available: chemical nerve block/lysis, radiofrequency ablation and neurostimulation. Some of these interventions are commonly performed in interventional pain clinics for treatment of headache resistant to conservative measures. Despite their use, the level of evidence for using SPG interventions varies widely across a myriad of conditions.

In this systematic review, we sought to systematically collect the evidence supporting the use of these SPG interventions in treating various painful conditions. We also summarized the level of evidence for each condition and intervention.

\section{Methods}

\section{Protocol}

This systematic review applies the guidelines issued in the latest Preferred Reporting Items for Systematic Reviews and Meta-Analysis (Additional file 1: PRISMA).

\section{Information sources}

The electronic databases of PubMed (https://www.ncbi.nlm.nih.gov/pubmed/), Cochrane Central Register of Controlled Trials (CENTRAL, www.cochranelibrary.com), Google Scholar (https://scholar.google.com/) were searched to identify relevant articles. Additionally, references within eligible papers were screened for additional articles.

\section{Literature search strategy}

The search was conducted in May 2017. The search strategy was based on the Population, Intervention, Comparator, Outcome (PICO) framework and was conducted to find studies on sphenopalatine ganglion block, radiofrequency ablation and neurostimulation. Population (P) was defined as patients suffering from any medical condition; intervention (I) was limited to sphenopalatine ganglion block, sphenopalatine radiofrequency ablation, and sphenopalatine ganglion neurostimulation; patients receiving interventions were compared $(C)$ to preintervention status, patients without treatment or healthy controls; the outcome $(\mathrm{O})$ needed to either qualitatively or quantitatively measure the reduction in disease severity with 
intervention. The complete entered search strategy in PubMed was: "(sphenopalatine) AND ganglion) AND block" for sphenopalatine ganglion block; "(sphenopalatine) AND ganglion) AND radiofrequency" for radiofrequency ablation; and (sphenopalatine AND ganglion AND neurostimulation) OR (sphenopalatine AND ganglion AND neuromodulation).

\section{Eligibility criteria and study selection}

To be included in this review, studies had to meet the following criteria: 1 . The study sample was human. 2 . Interventions must be SPG block, SPG radiofrequency ablation or SPG neurostimulation. 3. Articles had to be written in English. 4. Full-Text articles had to be available. 5. Conference abstracts and reviews were excluded.

\section{Data items and collection}

The following items were compiled in the evidence tables for SPG block (Table 2-12): first author, year of publication, medical condition treated, approach, imaging modality, medication used for the procedure, number of cases, study design and outcome. For radiofrequency ablation, the following additional items were collected: radiofrequency ablation temperature, type of radiofrequency ablation, parameter used and how to identify the correct position of the radiofrequency cannula/probe. For neurostimulation, the following additional items were collected: type of stimulator, type of stimulation and how to identify the correct position.

\section{Risk of bias assessment}

The quality of randomized-controlled studies was assessed using the 7-item criteria in Review Manager Software version 5.35 provided by the Cochrane Collaboration [5]. The 7-item criteria contained: (1) random sequence generation; (2) allocation concealment; (3) blinding of participants and personnel; (4) blinding of outcome assessment; (5) incomplete outcome data; (6) selective reporting and (7) other bias.

\section{Analysis of evidence and recommendations}

Level of evidence was graded based on Oxford Center for Evidence-based Medicine (1a: Systematic review of randomized-controlled trials. 1b: Individual randomizedcontrolled trials with narrow confidence interval. 2a: Systematic review of homogenous cohort studies. 2b: Individual cohort studies and low quality randomized-controlled trial. 3a: Systematic review of homogenous case-control studies. 3b: Individual case-control study. 4. Case series and poor-quality cohort and case-control studies. 5 . Expert opinion. Grade of recommendation: A: Consistent level 1 studies. B: Consistent level 2 or 3 studies or extrapolations from level 1 studies. C: Level 4 studies or extrapolations from level 2 or 3 studies. D: Level 5 evidence or troublingly inconsistent or inconclusive studies of any level. Risk of bias in individual studies and across studies were not systematically assessed as most studies included in this review were case reports and case series.

\section{Results}

\section{Overall summary}

The result of the search process is provided in Fig. 1. 60 articles were included for SPG block, 15 articles for SPG radiofrequency ablation, and 8 articles for SPG neurostimulation.

The evidence levels and grades of recommendation for SPG block, radiofrequency ablation and neurostimulation are summarized in Table 1. Any study with evidence level above case series is included in Table 2. Risk of bias of randomized-controlled studies is summarized in Fig. 2. Most randomized-controlled studies included in this review have adequate randomization and blinding of participants and personnel.

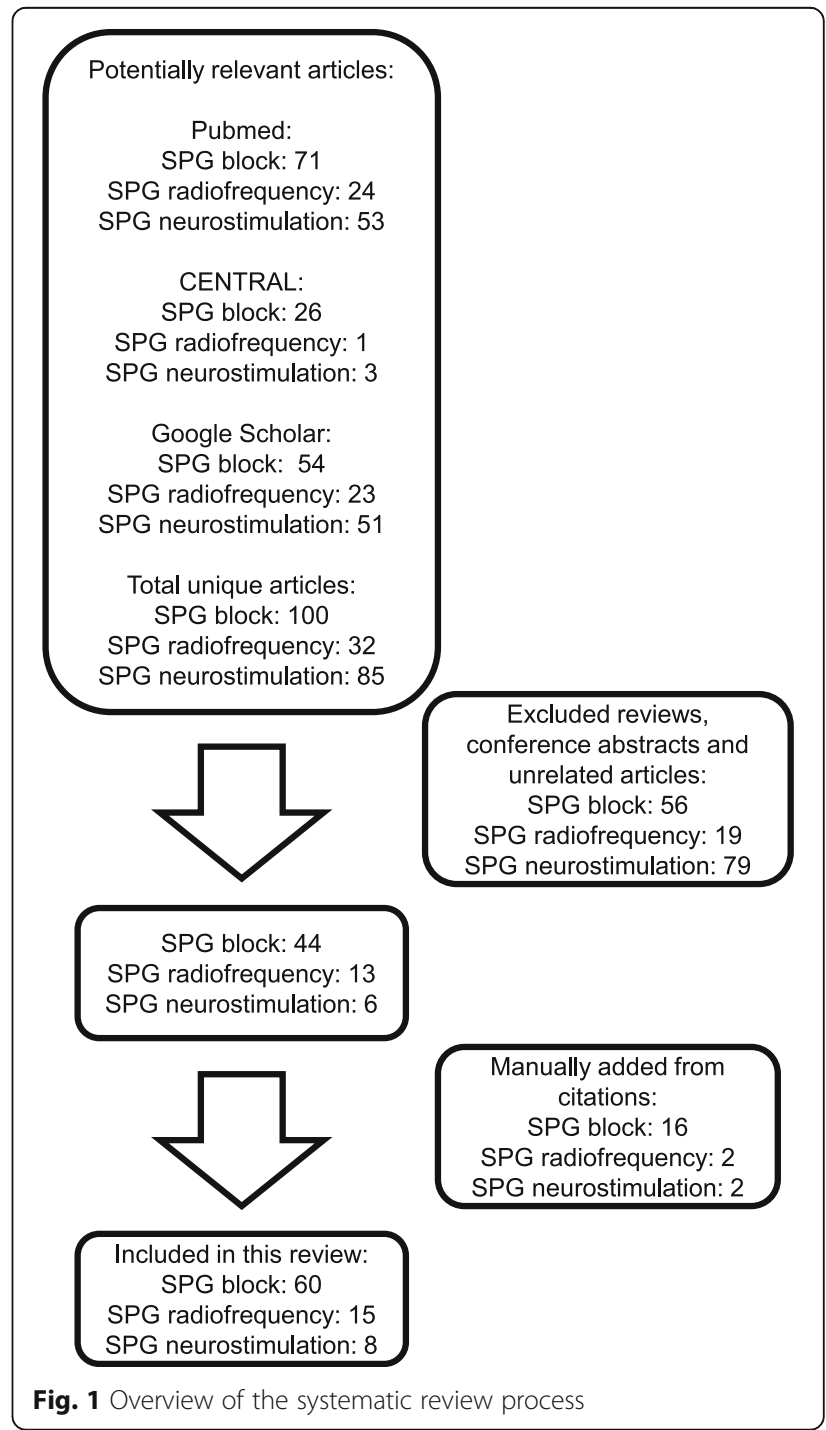


Table 1 Summary of evidence level and grade of recommendation for SPG block, radiofrequency ablation and neurostimulation

\begin{tabular}{|c|c|c|c|c|}
\hline Medical condition & $\begin{array}{l}\text { Application/ Medication } \\
\text { used in controlled } \\
\text { studies }\end{array}$ & $\begin{array}{l}\text { Number of } \\
\text { controlled } \\
\text { studies }\end{array}$ & $\begin{array}{l}\text { Highest level } \\
\text { of evidence }\end{array}$ & $\begin{array}{l}\text { Grade of } \\
\text { recommendation }\end{array}$ \\
\hline \multicolumn{5}{|l|}{ SPG block } \\
\hline Cluster headache & $\begin{array}{l}\text { Cotton swab/cocaine } \\
\text { or lidocaine }\end{array}$ & 1 & $2 b$ & B \\
\hline Second-division trigeminal neuralgia & Lidocaine spray & 1 & $2 b$ & B \\
\hline $\begin{array}{l}\text { Reducing the needs of analgesics } \\
\text { after endoscopic sinus surgery }\end{array}$ & $\begin{array}{l}\text { Needle injection, } \\
\text { transnasal and palatal } \\
\text { approach/lidocaine, } \\
\text { bupivacaine, I } \\
\text { evobupivacaine, } \\
\text { tetracaine }\end{array}$ & 6 & $1 b$ & B \\
\hline $\begin{array}{l}\text { Reducing the pain associated } \\
\text { with nasal packing removal } \\
\text { after nasal operation }\end{array}$ & $\begin{array}{l}\text { Needle injection, } \\
\text { infrazygomatic } \\
\text { approach/lidocaine }\end{array}$ & 1 & $3 b$ & B \\
\hline Migraine & Tx360 device/ bupivicane & 1 & $2 b$ & B \\
\hline $\begin{array}{l}\text { Postdural puncture headache, } \\
\text { sphenopalatine maxillary neuralgia, } \\
\text { facial neuralgia, sympathetic neuralgia, } \\
\text { post-traumatic atypical facial pain, } \\
\text { atypical odontalgia, pain from midline } \\
\text { granuloma, herpetic keratitis, hemifacial } \\
\text { headache,paroxysmal hemicrania, nasal } \\
\text { pain, hemicrania continua, trigeminal } \\
\text { neuropathy, cancer pain, seizures } \\
\text { associated nasal pathology, arthritic } \\
\text { pain and muscle spasm, intercostal } \\
\text { neuritis, persistent hiccups, ureteral } \\
\text { colic, dysmenorrhea, peripheral painful } \\
\text { vascular spasm, complex regional pain } \\
\text { syndrome and hypertension }\end{array}$ & Various protocols & 0 & 4 & C \\
\hline Myofascial pain & $\begin{array}{l}\text { Cotton-tipped applicator, } \\
\text { nasal spray/lidocaine }\end{array}$ & 2 & $2 b$ & Not recommended \\
\hline \multicolumn{5}{|l|}{ SPG radiofrequency ablation } \\
\hline Cluster headache & $\begin{array}{l}\text { Infrazygomatic approach } \\
180^{\circ} \mathrm{C}, 60 \mathrm{~s} \times 2\end{array}$ & 0 (1 cohort study) & $2 b$ & B \\
\hline $\begin{array}{l}\text { Sluder's neuralgia, posttraumatic } \\
\text { headache, chronic head and face pain, } \\
\text { atypical trigeminal neuralgia, atypical } \\
\text { facial pain, chronic facial pain secondary } \\
\text { to cavernous sinus meningioma, } \\
\text { trigeminal neuralgia, SPG neuralgia } \\
\text { due to herpes zoster }\end{array}$ & Various protocols & 0 & 4 & C \\
\hline \multicolumn{5}{|l|}{ SPG neurostimulation } \\
\hline Cluster headache & $\begin{array}{l}\text { Customized to each patient, } \\
\text { mean frequency } \\
120.4 \pm 15.5 \mathrm{~Hz} \\
\text { pulse width } 389.7 \pm 75.4 \mu \mathrm{s}, \\
\text { intensity } 1.6 \pm 0.8 \mathrm{~mA}\end{array}$ & 1 & $1 b$ & B \\
\hline Idiopathic facial pain, migraine & Various protocols & 0 & 4 & C \\
\hline
\end{tabular}

In the following sections, we will summarize the level of evidence and grades of recommendations by the type of SPG interventions and associated medical conditions.

\section{Sphenopalatine ganglion block}

Sixty articles were included for sphenopalatine ganglion block. Of the 60 studies, 11 were small randomized- controlled studies, and 1 was retrospective casecontrol study. The rest of the literature included case reports and case series. The type of blocking agent varied across studies, but they could be broadly put into three categories: cocaine, voltage-gated sodium channel blocker (local anesthetics), and a combination of voltage-gated sodium channel blocker and steroids. 
Table 2 Studies with evidence level above case series in SPG block, radiofrequency ablation and neurostimulation

\begin{tabular}{|c|c|c|c|c|c|c|c|c|}
\hline \multicolumn{9}{|c|}{ Evidence level above case series } \\
\hline Author & Year & $\begin{array}{l}\text { Medical } \\
\text { problems }\end{array}$ & Approach & Imaging & Medication & $\begin{array}{l}\text { Number } \\
\text { of cases }\end{array}$ & Study design & Outcome \\
\hline \multicolumn{9}{|l|}{ SPG Block } \\
\hline $\begin{array}{l}\text { Berger } \\
\text { et al. [32] }\end{array}$ & 1986 & Low back pain & $\begin{array}{l}\text { Cotton tip } \\
\text { applicator } \\
\text { and transnasal } \\
\text { needle }\end{array}$ & None & $\begin{array}{l}\text { Cocaine or } \\
\text { lidocaine }\end{array}$ & $\begin{array}{l}7 \text { cases with } \\
\text { cocaine, } 7 \text { cases } \\
\text { with lidocaine, } \\
7 \text { controls }\end{array}$ & Case-control & $\begin{array}{l}\text { No statistical } \\
\text { significance } \\
\text { between } \\
\text { cases and } \\
\text { controls }\end{array}$ \\
\hline $\begin{array}{l}\text { Slade et al. } \\
\text { [51] }\end{array}$ & 1986 & $\begin{array}{l}\text { Tear secretion } \\
\text { with topical } \\
\text { anesthesia }\end{array}$ & $\begin{array}{l}\text { Needle injection, } \\
\text { through the } \\
\text { greater palatine } \\
\text { foramen }\end{array}$ & None & $2 \%$ lidocaine & 10 & $\begin{array}{l}\text { Case-control } \\
\text { (using self as } \\
\text { control) }\end{array}$ & $\begin{array}{l}\text { Tear secretion } \\
\text { significantly } \\
\text { reduced } \\
\text { by } 73 \% \\
(p<0.001)\end{array}$ \\
\hline $\begin{array}{l}\text { Henneberger } \\
\text { et al. [36] }\end{array}$ & 1988 & $\begin{array}{l}\text { Nicotine } \\
\text { addiction }\end{array}$ & $\begin{array}{l}\text { Cotton tipped } \\
\text { applicator, } \\
\text { transnasal } \\
\text { approach }\end{array}$ & None & $\begin{array}{l}\text { Bupivacaine, } \\
\text { cocaine or } \\
\text { saline }\end{array}$ & $\begin{array}{l}6 \text { with bupivacaine, } \\
5 \text { with cocaine, } \\
6 \text { with saline }\end{array}$ & $\begin{array}{l}\text { Double-blind } \\
\text { placebo- } \\
\text { controlled }\end{array}$ & $\begin{array}{l}\text { Significantly } \\
\text { fewer symptoms } \\
\text { of discomfort for } \\
\text { patients in the } \\
\text { anesthetic } \\
\text { treatment } \\
\text { groups } \\
\text { than placebo } \\
\text { group }\end{array}$ \\
\hline $\begin{array}{l}\text { Silverman } \\
\text { et al. [37] }\end{array}$ & 1993 & $\begin{array}{l}\text { Experimentally } \\
\text { induced pain } \\
\text { (submaximal } \\
\text { effort tourniquet } \\
\text { test) }\end{array}$ & $\begin{array}{l}\text { Cotton tipped } \\
\text { applicator }\end{array}$ & None & $\begin{array}{l}20 \% \text { lidocaine } \\
\text { and epinephrine }\end{array}$ & $\begin{array}{l}16 \text { healthy } \\
\text { volunteers }\end{array}$ & $\begin{array}{l}\text { Double-blind, } \\
\text { cross-over study }\end{array}$ & $\begin{array}{l}\text { No significant } \\
\text { difference } \\
\text { between } \\
\text { experimental } \\
\text { and placebo } \\
\text { group. }\end{array}$ \\
\hline $\begin{array}{l}\text { Scudds et al. } \\
\text { [3] }\end{array}$ & 1995 & $\begin{array}{l}\text { Chronic muscle } \\
\text { pain syndrome }\end{array}$ & $\begin{array}{l}\text { Cotton tipped } \\
\text { applicator, } \\
\text { transnasal } \\
\text { approach }\end{array}$ & None & $4 \%$ lidocaine & $\begin{array}{l}42 \text { with } \\
\text { fibromyalgia, } \\
19 \text { with myofascial } \\
\text { pain syndrome }\end{array}$ & $\begin{array}{l}\text { Double-blind } \\
\text { randomized } \\
\text { controlled }\end{array}$ & $\begin{array}{l}\text { No statistical } \\
\text { significance } \\
\text { between } \\
4 \% \text { lidocaine } \\
\text { and placebo }\end{array}$ \\
\hline $\begin{array}{l}\text { Janzen et al. } \\
{[30]}\end{array}$ & 1997 & $\begin{array}{l}\text { Myofascial pain } \\
\text { syndrome and } \\
\text { fibromyalgia }\end{array}$ & Nasal spray & None & $4 \%$ lidocaine & $\begin{array}{l}42 \text { with } \\
\text { fibromyalgia, } \\
19 \text { with myofascial } \\
\text { pain syndrome }\end{array}$ & $\begin{array}{l}\text { Double-blind, } \\
\text { placebo- } \\
\text { controlled }\end{array}$ & $\begin{array}{l}\text { No statistical } \\
\text { significance } \\
\text { between } 4 \% \\
\text { lidocaine and } \\
\text { placebo }\end{array}$ \\
\hline $\begin{array}{l}\text { Ferrante } \\
\text { et al. [31] }\end{array}$ & 1998 & $\begin{array}{l}\text { Myofascial pain } \\
\text { syndrome of the } \\
\text { head, neck and } \\
\text { shoulders }\end{array}$ & NA & None & $4 \%$ lidocaine & $\begin{array}{l}13 \text { cases, } \\
7 \text { controls }\end{array}$ & $\begin{array}{l}\text { Double-blind, } \\
\text { placebo-controlled, } \\
\text { crossover design }\end{array}$ & $\begin{array}{l}\text { No statistical } \\
\text { significance }\end{array}$ \\
\hline $\begin{array}{l}\text { Costa et al. } \\
\text { [6] }\end{array}$ & 2000 & $\begin{array}{l}\text { Cluster } \\
\text { headache } \\
\text { (nitroglycerin } \\
\text { induced) }\end{array}$ & $\begin{array}{l}\text { Cotton tipped } \\
\text { applicator, } \\
\text { transnasal } \\
\text { approach }\end{array}$ & None & $\begin{array}{l}10 \% \text { cocaine or } \\
10 \% \text { lidocaine }\end{array}$ & $\begin{array}{l}6 \text { episodic } \mathrm{CH} \\
9 \text { chronic } \mathrm{CH}\end{array}$ & $\begin{array}{l}\text { Double-blind, } \\
\text { placebo- } \\
\text { controlled, }\end{array}$ & $\begin{array}{l}\text { All patients } \\
\text { with induced } \\
\text { pain responded } \\
\text { to cocaine after } \\
31.3 \text { min and } \\
\text { lidocaine after } \\
37 \text { min }\end{array}$ \\
\hline $\begin{array}{l}\text { Hwang et al. } \\
{[23]}\end{array}$ & 2003 & $\begin{array}{l}\text { Removal of } \\
\text { nasal packing } \\
\text { after nasal } \\
\text { operation }\end{array}$ & $\begin{array}{l}\text { Needle injection } \\
\text { into the greater } \\
\text { palatine canal }\end{array}$ & None & $1 \%$ lidocaine & 11 & Case-control & $\begin{array}{l}\text { Injection } \\
\text { side had } \\
\text { significantly } \\
\text { lower pain } \\
\text { than the } \\
\text { control side }\end{array}$ \\
\hline $\begin{array}{l}\text { Kanai et al. } \\
\text { [11] }\end{array}$ & 2006 & $\begin{array}{l}\text { Second division } \\
\text { trigeminal } \\
\text { neuralgia }\end{array}$ & Nasal spray & None & Lidocaine & 25 & $\begin{array}{l}\text { Randomized } \\
\text { control }\end{array}$ & $\begin{array}{l}\text { Significantly } \\
\text { decreased pain } \\
\text { with intranasal } \\
\text { lidocaine spray }\end{array}$ \\
\hline $\begin{array}{l}\text { Ahmed et al. } \\
{[18]}\end{array}$ & 2007 & $\begin{array}{l}\text { Sinonasal } \\
\text { surgery } \\
\text { intraoperative } \\
\text { isofluorane } \\
\text { consumption, } \\
\text { hypotensive } \\
\text { agents used, } \\
\text { postoperative } \\
\text { pain }\end{array}$ & $\begin{array}{l}\text { Bilateral SPG block, } \\
\text { injected between } \\
\text { the middle and } \\
\text { inferior turbinates }\end{array}$ & None & $\begin{array}{l}0.5 \% \text { lidocaine } \\
\text { and epinephrine. }\end{array}$ & $\begin{array}{l}15 \text { cases, } 15 \\
\text { controls }\end{array}$ & $\begin{array}{l}\text { Randomized- } \\
\text { controlled }\end{array}$ & $\begin{array}{l}\text { Significantly } \\
\text { reduced } \\
\text { intraoperative } \\
\text { isofluorane } \\
\text { consumption } \\
\text { and esmolol } \\
\text { use, postoperative } \\
\text { tramadol use and } \\
\text { postoperative pain. }\end{array}$ \\
\hline Ali et al. [20] & 2010 & $\begin{array}{l}\text { Endoscopic } \\
\text { trans-nasal } \\
\text { resection of } \\
\text { pituitary } \\
\text { adenoma, } \\
\text { anesthetic, } \\
\text { vasodilator } \\
\text { and analgesic } \\
\text { sparing effect }\end{array}$ & $\begin{array}{l}\text { Bilateral SPG block, } \\
\text { injected between } \\
\text { the middle and } \\
\text { inferior turbinates }\end{array}$ & None & $\begin{array}{l}\text { 1.5\% lidocaine } \\
\text { and epinephrine }\end{array}$ & $\begin{array}{l}15 \text { cases and } \\
15 \text { controls }\end{array}$ & $\begin{array}{l}\text { Randomized- } \\
\text { controlled }\end{array}$ & $\begin{array}{l}\text { Significantly } \\
\text { reduced in } \\
\text { sevoflurane } \\
\text { and nitroglycerine } \\
\text { consumption, } \\
\text { emergence time, } \\
\text { postoperative } \\
\text { pain and need } \\
\text { of meperidine } \\
\text { analgesia. }\end{array}$ \\
\hline
\end{tabular}


Table 2 Studies with evidence level above case series in SPG block, radiofrequency ablation and neurostimulation (Continued)

\begin{tabular}{|c|c|c|c|c|c|c|c|c|}
\hline \multicolumn{9}{|c|}{ Evidence level above case series } \\
\hline Author & Year & $\begin{array}{l}\text { Medical } \\
\text { problems }\end{array}$ & Approach & Imaging & Medication & $\begin{array}{l}\text { Number } \\
\text { of cases }\end{array}$ & Study design & Outcome \\
\hline $\begin{array}{l}\text { Cho et al. } \\
{[17]}\end{array}$ & 2011 & $\begin{array}{l}\text { Endoscopic } \\
\text { sinus surgery } \\
\text { postoperative } \\
\text { analgesia } \\
\text { efficacy }\end{array}$ & $\begin{array}{l}\text { Transoral, through } \\
\text { the greater } \\
\text { palatine foramen }\end{array}$ & None & $\begin{array}{l}0.25 \% \\
\text { bupivacaine } \\
\text { with } \\
\text { epinephrine }\end{array}$ & 60 & $\begin{array}{l}\text { Double-blind } \\
\text { randomized, } \\
\text { placebo } \\
\text {-controlled }\end{array}$ & $\begin{array}{l}\text { Pain not } \\
\text { significantly } \\
\text { different from } \\
\text { control }\end{array}$ \\
\hline $\begin{array}{l}\text { Kesimci et al. } \\
\text { [22] }\end{array}$ & 2012 & $\begin{array}{l}\text { Endoscopic } \\
\text { sinus surgery } \\
\text { postoperative } \\
\text { analgesia } \\
\text { efficacy }\end{array}$ & $\begin{array}{l}\text { Bilateral SPG block, } \\
\text { injected between } \\
\text { the middle and inferior turbinates }\end{array}$ & None & $\begin{array}{l}0.5 \% \\
\text { bupivacaine } \\
\text { or } 0.5 \% \\
\text { levobupivacaine }\end{array}$ & 45 & $\begin{array}{l}\text { Double-blind } \\
\text { randomized, } \\
\text { placebo- } \\
\text { controlled }\end{array}$ & $\begin{array}{l}\text { Postoperative } \\
\text { pain significantly } \\
\text { reduced, also } \\
\text { significantly } \\
\text { few patients } \\
\text { requiring } \\
\text { additional } \\
\text { analgesics } \\
\text { in the } \\
\text { postoperative } \\
24 \text { h. }\end{array}$ \\
\hline $\begin{array}{l}\text { Demaria } \\
\text { et al. [21] }\end{array}$ & 2012 & $\begin{array}{l}\text { Endoscopic } \\
\text { sinus surgery } \\
\text { postoperative } \\
\text { analgesia } \\
\text { efficacy }\end{array}$ & $\begin{array}{l}\text { Bilateral SPG block, } \\
\text { palatal approach }\end{array}$ & None & $\begin{array}{l}2 \% \text { lidocaine } \\
\text { and } 1 \% \\
\text { tetracaine }\end{array}$ & 70 & $\begin{array}{l}\text { Double-blind } \\
\text { randomized, } \\
\text { placebo- } \\
\text { controlled }\end{array}$ & $\begin{array}{l}\text { Patients were } \\
\text { discharged } \\
\text { sooner than } \\
\text { the control } \\
\text { group. The } \\
\text { block group } \\
\text { also required } \\
\text { less total } \\
\text { fentanyl in } \\
\text { the recovery } \\
\text { room. }\end{array}$ \\
\hline $\begin{array}{l}\text { Cady et al. } \\
{[15]}\end{array}$ & 2015 & $\begin{array}{l}\text { Chronic } \\
\text { migraine }\end{array}$ & $T \times 360$ & None & $\begin{array}{l}0.5 \% \\
\text { bupivacaine }\end{array}$ & 38 & $\begin{array}{l}\text { Double blind, } \\
\text { placebo control }\end{array}$ & $\begin{array}{l}\text { Significantly } \\
\text { decreased } \\
\text { headache } \\
\text { at } 24 \mathrm{~h}\end{array}$ \\
\hline $\begin{array}{l}\text { Cady et al. } \\
{[16]}\end{array}$ & 2015 & $\begin{array}{l}\text { Chronic } \\
\text { migraine }\end{array}$ & $\begin{array}{l}\text { Repetitive block } \\
\text { (twice a week) } \\
\text { with Tx360 }\end{array}$ & None & $\begin{array}{l}0.5 \% \\
\text { bupivacaine }\end{array}$ & 38 & $\begin{array}{l}\text { Double blind, } \\
\text { placebo control }\end{array}$ & $\begin{array}{l}\text { No statistical } \\
\text { difference at } \\
1 \text { month and } \\
6 \text { months } \\
\text { between } \\
\text { treatment } \\
\text { and control } \\
\text { groups. }\end{array}$ \\
\hline $\begin{array}{l}\text { Schaffer } \\
\text { et al. [34] }\end{array}$ & 2015 & $\begin{array}{l}\text { Acute anterior } \\
\text { or global } \\
\text { headache }\end{array}$ & Tx360 device & None & $\begin{array}{l}0.5 \% \\
\text { bupivacaine }\end{array}$ & 93 & $\begin{array}{l}\text { Randomized } \\
\text { placebo- } \\
\text { controlled }\end{array}$ & $\begin{array}{l}\text { No statistically } \\
\text { significant } \\
\text { difference }\end{array}$ \\
\hline $\begin{array}{l}\text { Al-Qudah } \\
\text { et al. [19] }\end{array}$ & 2015 & $\begin{array}{l}\text { Endoscopic } \\
\text { sinus surgery } \\
\text { postoperative } \\
\text { analgesia } \\
\text { efficacy }\end{array}$ & $\begin{array}{l}\text { Applied to } \\
\text { the SPG } \\
\text { region }\end{array}$ & None & $\begin{array}{l}2 \% \text { lidocaine } \\
\text { and } \\
\text { epinephrine }\end{array}$ & $\begin{array}{l}60 \text { (30 cases, } \\
30 \text { controls) }\end{array}$ & $\begin{array}{l}\text { Double-blind, } \\
\text { placebo } \\
\text { controlled }\end{array}$ & $\begin{array}{l}\text { Significant } \\
\text { pain reduction } \\
\text { in the SPG } \\
\text { block group }\end{array}$ \\
\hline $\begin{array}{l}\text { Narouze } \\
\text { et al. [38] }\end{array}$ & 2009 & $\begin{array}{l}\text { Chronic cluster } \\
\text { headache }\end{array}$ & $\begin{array}{l}\text { Infrazygomatic } \\
\text { approach }\end{array}$ & Fluoroscopy & NA & 15 & $\begin{array}{l}\text { Prospective } \\
\text { cohort }\end{array}$ & $\begin{array}{l}\text { Mean attack } \\
\text { intensity, } \\
\text { mean attack } \\
\text { frequency, } \\
\text { pain disability } \\
\text { index significant } \\
\text { reduced at } 1 \\
\text { year follow-up } \\
(P<0.0005 \text {, } \\
P<0.0003 \text {, } \\
P<0.002 \text {, } \\
\text { respectively })\end{array}$ \\
\hline \multicolumn{9}{|l|}{ SPG Neurostimulation } \\
\hline $\begin{array}{l}\text { Schoenen } \\
\text { et al. [41] }\end{array}$ & 2013 & $\begin{array}{l}\text { Cluster } \\
\text { headache }\end{array}$ & $\begin{array}{l}\text { ATI SPG } \\
\text { stimulator } \\
\text { positioned on the } \\
\text { lateral-posterior } \\
\text { maxilla medial } \\
\text { to the zygoma. } \\
\text { Customized, } \\
\text { mean frequency } \\
120.4 \mathrm{~Hz} \text {, mean } \\
\text { pulse width } 389.7 \\
\text { us, mean intensity } \\
1.6 \mathrm{~mA}\end{array}$ & $\subset$ & - & $\begin{array}{l}28 \text { cases, } \\
\text { with } 3 \\
\text { randomized } \\
\text { settings. }\end{array}$ & $\begin{array}{l}\text { Randomized } \\
\text { controlled }\end{array}$ & $\begin{array}{l}\text { Pain relief } \\
\text { achieved in } \\
67.1 \% \text { of } \\
\text { full stimulation- } \\
\text { treated attacks } \\
\text { compared to } \\
7.4 \% \text { of sham- } \\
\text { treated attacks. } \\
P<0.0001\end{array}$ \\
\hline Jurgens et al. [42] & 2016 & Cluster headache & $\begin{array}{l}\text { Neurostimulator, } \\
\text { described in } \\
\text { Schoenen } \\
\text { et al. [41] }\end{array}$ & $C T$ & - & 33 cases & $\begin{array}{l}\text { Cohort study. } \\
\text { Long-term } \\
\text { follow-up } \\
\text { from [41] }\end{array}$ & $\begin{array}{l}61 \% \text { of } \\
\text { patients } \\
\text { were either } \\
\text { acute } \\
\text { responder } \\
(>50 \% \text { relief }\end{array}$ \\
\hline
\end{tabular}


Table 2 Studies with evidence level above case series in SPG block, radiofrequency ablation and neurostimulation (Continued)

\begin{tabular}{|c|c|c|c|c|c|c|c|c|}
\hline \multicolumn{9}{|c|}{ Evidence level above case series } \\
\hline Author & Year & $\begin{array}{l}\text { Medical } \\
\text { problems }\end{array}$ & Approach & Imaging & Medication & $\begin{array}{l}\text { Number } \\
\text { of cases }\end{array}$ & Study design & Outcome \\
\hline & & & & & & & & $\begin{array}{l}\text { from } \\
\text { moderate } \\
\text { or greater } \\
\text { pain) or } f \\
\text { requency } \\
\text { responder } \\
(>50 \% \text { in } \\
\text { attack } \\
\text { frequency) } \\
\text { at } 24 \text { months }\end{array}$ \\
\hline Barloese et al. [43] & 2016 & Cluster headache & $\begin{array}{l}\text { Neurostimulator, } \\
\text { described in } \\
\text { Schoenen } \\
\text { et al. [41] }\end{array}$ & CT & - & 33 cases & $\begin{array}{l}\text { Cohort study. } \\
\text { Long-term } \\
\text { follow-up } \\
\text { from [41] }\end{array}$ & $\begin{array}{l}30 \% \\
\text { experienced } \\
\text { at least } 1 \\
\text { episode of } \\
\text { complete } \\
\text { attack } \\
\text { remission } \\
\text { (attack-free } \\
\text { period } \\
\text { exceeding } \\
1 \text { month) }\end{array}$ \\
\hline
\end{tabular}

Voltage-gated sodium channel blocker is the most commonly used agent.

\section{Cluster headache}

There were nine articles on chronic cluster headaches collected through our literature search (see Table 3). One was a small double-blind placebo-controlled study (level 2b), six were case series and two were case reports (level 4, see Table 3). Costa et al. [6] reported a doubleblind, placebo-controlled study using 15 cases of episodic and chronic cluster headaches. Cluster headache was induced with nitroglycerin, and SPG was treated with $10 \%$ solution of cocaine hydrochloride $(1 \mathrm{ml}$, mean amount of application of $40-50 \mathrm{mg}$ ), $10 \%$ lidocaine $(1 \mathrm{ml})$ or saline using a cotton swab previously immersed in these solutions. The cotton swab was placed in the region corresponding to the sphenopalatine fossa under anterior rhinoscopy. This was done in both the symptomatic and the non-symptomatic sides for $5 \mathrm{~min}$. Patients treated with cocaine and lidocaine reported relief in $31.3 \mathrm{~min}$ in the cocaine group and $37 \mathrm{~min}$ for lidocaine group, compared to $59.3 \mathrm{~min}$ in the saline group. The side effect was mainly the unpleasant taste of lidocaine. This study was limited by its small number of participants, the acutely induced cluster headache from nitroglycerin, and its measure on only short-term outcome.

Other case reports/series using cocaine and local anesthetics as blocking agents generally reported good immediate outcomes for aborting acute cluster headache. One study using cocaine reported 10 out of 11 patients receiving $50-100 \%$ relief from spontaneous cluster headache [7], another study using lidocaine reported four out of five patients receiving relief from nitrate-induced cluster headache [8]. Because of the short-term relief from cocaine and lidocaine, steroid has been tried to prolong the relief provided by SPG block. In one case series, combination of triamcinolone, bupivacaine, mepivacaine and epinephrine helped improve severity and frequency of cluster headaches in 11 out of 21 patients [9]. The same cocktail helped $55 \%$ of the 15 treated patients in another case series [10].

In summary, SPG block has moderate evidence in treating cluster headache. The overall grade of recommendation is B for SPG block on cluster headache. The strongest evidence lies in aborting nitroglycerin-induced cluster headache using local application of cocaine or lidocaine with cotton swab through the transnasal approach. The side effect was mainly the unpleasant taste of lidocaine. Addition of steroid may provide longer relief, but the evidence remains weak (Grade C recommendation).

\section{Trigeminal neuralgia}

There were four articles on SPG block for trigeminal neuralgia through our literature search. One was a randomized-controlled study (level $2 \mathrm{~b}$ ), two were case series and one case report (level 4, see Table 4). Kanai et al. performed a randomized-controlled study with 25 participants with refractory second-division trigeminal neuralgia [11]. In this study, twenty-five patients with second-division trigeminal neuralgia were randomized to receive two sprays $(0.2 \mathrm{ml})$ of either lidocaine $8 \%$ or saline placebo in the affected nostril using a metered-dose spray. The paroxysmal pain triggered by touching or moving face was assessed. Intranasal lidocaine $8 \%$ spray significantly decreased the paroxysmal pain for an average of $4.3 \mathrm{~h}$. The side effects were limited to local irritation with burning, stinging or numbness of the nose and eye, and bitter taste and numbness of the throat. One case series [12] and one case report [13] reported immediate pain relief from nerve blocks with lidocaine and 


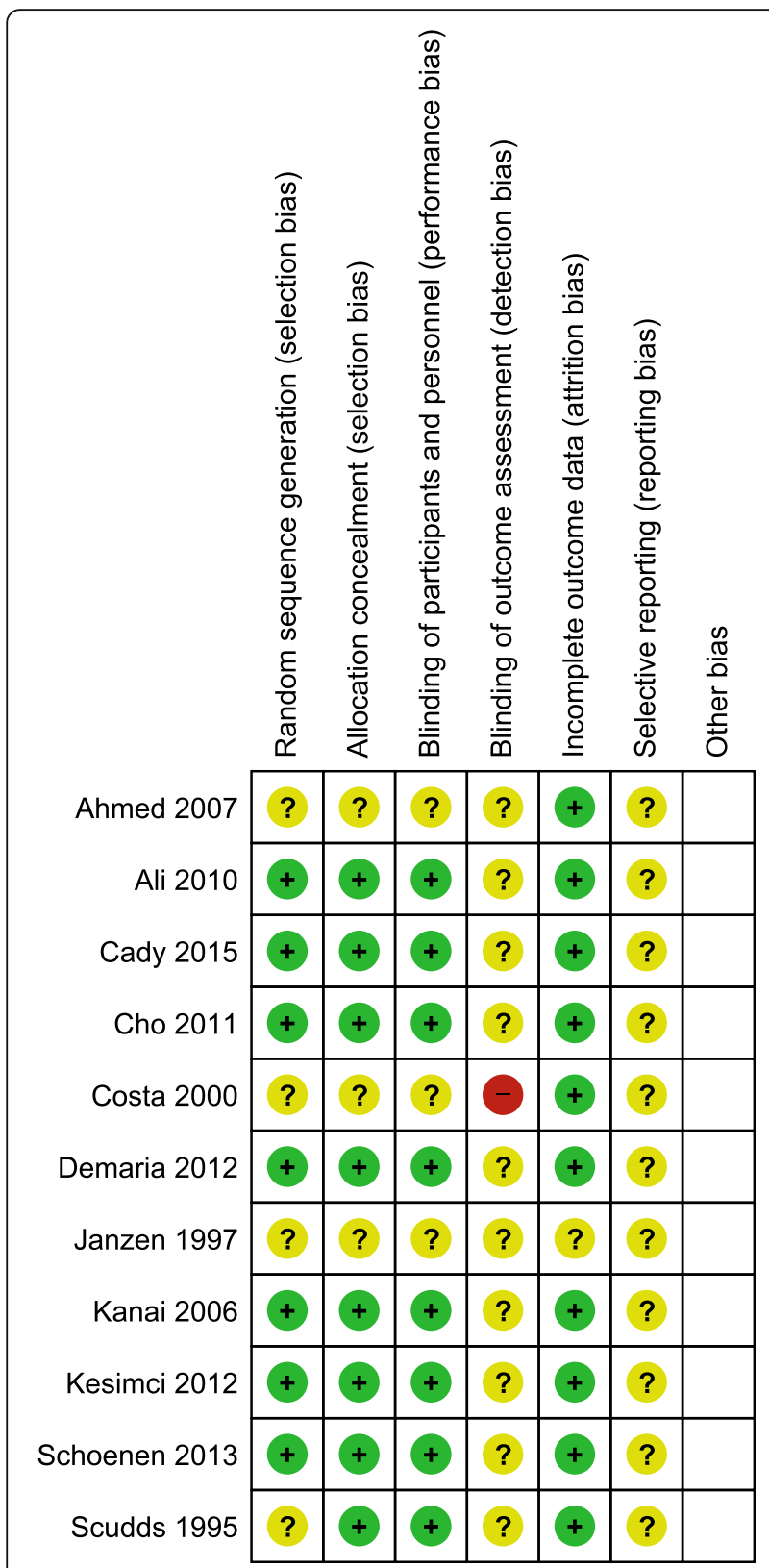

Fig. 2 Risk of bias summary of randomized-controlled studies

bupivacaine. One case series used a combination of dexamethasone and ropivacaine with the Tx360 applicator, which resulted in short-term pain relief [14]. Multiple blocks over time seemed to provide longer pain relief but it was restricted to isolated cases.

In summary, the overall grade of recommendation is B for SPG block on trigeminal neuralgia. The strongest evidence lies in treating with $8 \%$ lidocaine nasal spray in the affected nostril. The analgesia is effective but temporary $(4.3 \mathrm{~h})$. It is well-tolerated with side effects limited to local irritations. Addition of steroid and use of the Tx360 applicator may be useful but there has not been a controlled study.

\section{Migraine}

There was one small double-blind, placebo-controlled study and one long-term follow-up of the same study (level 2b), two case series and one case report (level 4, see Table 5). Cady et al. [15] reported a randomizedcontrolled study using the Tx360 device and bupivacaine to acutely treat chronic migraines with repetitive SPG blockade. 38 subjects with chronic migraines were included in the final analysis. Participants received a series of 12 SPG blocks with either $0.3 \mathrm{~cm}^{3}$ of $0.5 \%$ bupivacaine or saline delivered with the Tx $360^{\circ}$ through each nostril, over a 6-week period (2 SPG blocks/week). SPG block was found to be effective in reducing the severity of migraines up to $24 \mathrm{~h}$. However, repetitive blocks did not provide any statistically significant relief at 1-month or 6-month follow-ups [16]. The most common side effects were mouth numbness, lacrimation, and bad taste, but there was no statistical difference in frequency of side effects between the bupivacaine and saline groups.

Given the positive randomized-controlled study, grade of recommendation is B for short term treatment of chronic migraines using $0.5 \%$ bupivacaine with the Tx360 device ${ }^{\circ}$. It should be noted that the effect is only present for $24 \mathrm{~h}$. and it is not suitable for patients seeking relief greater than $24 \mathrm{~h}$.

\section{Postoperative pain of the head and face}

There were six randomized-controlled studies, one casecontrol study and one case series falling under this category (Table 6).

Six randomized-controlled studies examined the efficacy of SPG blockade in reducing the needs of analgesics after endoscopic sinus surgery (level $2 \mathrm{~b}$ ). One study by Cho et al. [17] did not show significant difference between SPG block and placebo, but five additional randomized-controlled studies showed significant reduction in the need of post-operative analgesics in the group treated with SPG block [18-22]. The five positive studies used $0.5 \%$ lidocaine with epinephrine [18], 1.5\% lidocaine with epinephrine [22], $0.5 \%$ bupivacaine or $0.5 \%$ levobupivacaine [22], $2 \%$ lidocaine and $1 \%$ tetracaine [21]. The SPG block was applied using injections, bilaterally through the transnasal or palatal approach. There was no difference in complications between the treatment and placebo group.

Hwang et al. [23] reported a case-control study to assess the efficacy of SPG block in reducing the pain associated with nasal packing removal after nasal operation (level 3b). 1\% lidocaine was injected into the greater palatine canal ipsilaterally using infrazygomatic approach. Participants reported significantly lower pain on the side of the nose that received SPG block compared to the control side. 
Table 3 Studies of SPG block for cluster headache

\begin{tabular}{|c|c|c|c|c|c|c|c|c|}
\hline \multicolumn{9}{|c|}{ Cluster headache } \\
\hline Author & Year & Medical problems & Approach & Imaging & Medication & $\begin{array}{l}\text { Number } \\
\text { of cases }\end{array}$ & $\begin{array}{l}\text { Study } \\
\text { design }\end{array}$ & Outcome \\
\hline $\begin{array}{l}\text { Devoghel } \\
\text { et al. [52] }\end{array}$ & 1981 & Cluster headache & $\begin{array}{l}\text { Needle injection. } \\
\text { Supra-zygomatic } \\
\text { approach }\end{array}$ & None & Pure alcohol & 120 & $\begin{array}{l}\text { Case } \\
\text { series }\end{array}$ & $\begin{array}{l}85.8 \% \text { had } \\
\text { complete relief }\end{array}$ \\
\hline $\begin{array}{l}\text { Barre et al. } \\
{[7]}\end{array}$ & 1982 & Cluster headache & $\begin{array}{l}\text { Cotton swab. } \\
\text { Applied to } \\
\text { sphenopalatine } \\
\text { foramen. } \\
\text { Self-application } \\
\text { if responded to } \\
\text { treatment }\end{array}$ & None & $\begin{array}{l}50 \text { mg of cocaine } \\
\text { flakes, then } 10 \% \\
\text { and } 5 \% \text { cocaine } \\
\text { solution }\end{array}$ & 11 & $\begin{array}{l}\text { Case } \\
\text { series }\end{array}$ & $\begin{array}{l}10 \text { out of } 11 \text { had } \\
50-100 \% \text { abortion } \\
\text { rate in spontaneous } \\
\text { headache }\end{array}$ \\
\hline $\begin{array}{l}\text { Kittrelle } \\
\text { et al. [8] }\end{array}$ & 1985 & Cluster headache & $\begin{array}{l}\text { Lidocaine directly } \\
\text { dropped into } \\
\text { the nostrils }\end{array}$ & None & $4 \%$ lidocaine & 5 & $\begin{array}{l}\text { Case } \\
\text { series }\end{array}$ & $\begin{array}{l}4 \text { of } 5 \text { patients } \\
\text { obtained relief } \\
\text { of nitrate-induced } \\
\text { cluster headaches }\end{array}$ \\
\hline $\begin{array}{l}\text { Costa et al. } \\
{[6]}\end{array}$ & 2000 & $\begin{array}{l}\text { Cluster headache } \\
\text { (nitroglycerin } \\
\text { induced) }\end{array}$ & $\begin{array}{l}\text { Cotton tipped } \\
\text { applicator, } \\
\text { transnasal } \\
\text { approach }\end{array}$ & None & $\begin{array}{l}10 \% \text { cocaine or } \\
10 \% \text { lidocaine }\end{array}$ & $\begin{array}{l}6 \text { episodic } \mathrm{CH} \\
9 \text { chronic } \mathrm{CH}\end{array}$ & $\begin{array}{l}\text { Double- } \\
\text { blind, } \\
\text { placebo- } \\
\text { controlled, }\end{array}$ & $\begin{array}{l}\text { All patients with } \\
\text { induced pain } \\
\text { responded to } \\
\text { cocaine after } \\
31.3 \text { min and } \\
\text { lidocaine after } \\
37 \text { min }\end{array}$ \\
\hline $\begin{array}{l}\text { Felisati et al. } \\
\text { [9] }\end{array}$ & 2006 & $\begin{array}{l}\text { Chronic cluster } \\
\text { headache }\end{array}$ & $\begin{array}{l}\text { Endoscopic } \\
\text { needle injection } \\
\text { that approaches } \\
\text { the pterygopalatine } \\
\text { fossa by way of the } \\
\text { lateral nasal wall }\end{array}$ & None & $\begin{array}{l}\text { Triamcinolone } \\
\text { acetonide, } 1 \% \\
\text { bupivacaine } \\
\text { and } 2 \% \\
\text { mepivacaine } \\
\text { with adrenaline }\end{array}$ & 21 & $\begin{array}{l}\text { Case } \\
\text { series }\end{array}$ & $\begin{array}{l}11 \text { out of } 21 \text { have } \\
\text { improvement in } \\
\text { symptoms }\end{array}$ \\
\hline $\begin{array}{l}\text { Yang et al. } \\
\text { [53] }\end{array}$ & 2006 & $\begin{array}{l}\text { Chronic cluster } \\
\text { headache }\end{array}$ & Transnasal needle & Fluoroscopy & $\begin{array}{l}0.2 \% \text { Ropivacaine } \\
\text { and triamcinolone }\end{array}$ & 1 & $\begin{array}{l}\text { Case } \\
\text { report }\end{array}$ & $60 \%$ pain relief \\
\hline $\begin{array}{l}\text { Pipolo et al. } \\
\text { [10] }\end{array}$ & 2010 & $\begin{array}{l}\text { Drug-resistant } \\
\text { chronic cluster } \\
\text { headache }\end{array}$ & $\begin{array}{l}\text { Needle into the } \\
\text { inferior portion } \\
\text { of the sphenopalatine } \\
\text { foramen (transnasal } \\
\text { endoscopic } \\
\text { technique- } \\
\text { prasanna } 1993\end{array}$ & None & $\begin{array}{l}40 \mathrm{mg} \\
\text { triamcinolone } \\
\text { acetonide, } \\
1 \% \text { bupivacaine, } \\
2 \% \text { mepivacaine } \\
\text { with adrenaline }\end{array}$ & 15 & Case series & $\begin{array}{l}\text { 55\% experience } \\
\text { complete subsidence } \\
\text { of } \mathrm{CH} \text { symptoms }\end{array}$ \\
\hline $\begin{array}{l}\text { Zarembinski } \\
\text { et al. [54] }\end{array}$ & 2014 & $\begin{array}{l}\text { Drug-resistant } \\
\text { chronic cluster } \\
\text { headache, } \\
\text { with Jacob's } \\
\text { disease }\end{array}$ & $\begin{array}{l}\text { Sphenopalatine } \\
\text { ganglion block } \\
\text { via mandibular } \\
\text { notch, then } \\
\text { radiofrequency } \\
\text { oblation. }\end{array}$ & $\begin{array}{l}\text { Fluoroscopy, } \\
\text { CT }\end{array}$ & $\begin{array}{l}0.25 \% \\
\text { bupivacaine and } \\
10 \mathrm{mg} / \mathrm{ml} \\
\text { dexamethasone }\end{array}$ & 1 & Case report & $\begin{array}{l}\text { Pain significantly } \\
\text { improved. }\end{array}$ \\
\hline $\begin{array}{l}\text { Kastler et al. } \\
\text { [55] }\end{array}$ & 2014 & $\begin{array}{l}\text { Cluster headache } \\
\text { (14), persistent } \\
\text { idiopathic facial } \\
\text { pain (10), and } \\
\text { other types of } \\
\text { facial pain (18) }\end{array}$ & $\begin{array}{l}\text { Infrazygomatic } \\
\text { approach }\end{array}$ & $\mathrm{CT}$ & Absolute alcohol & 14 & $\begin{array}{l}\text { Case } \\
\text { series }\end{array}$ & $\begin{array}{l}76.5 \% \text { of patients } \\
\text { have } 50 \% \text { pain } \\
\text { relief at } 1 \text { month }\end{array}$ \\
\hline
\end{tabular}

Robiony et al. [24] reported one case series (level 4) on the effectiveness of combined maxillary transcutaneous nerve block and SPG block in reducing postoperative pain for surgical correction of skeletal transverse discrepancy of the maxilla.

Given five positive double-blind placebo-controlled studies and one negative study, the grade of recommendation is B for SPG block in improving postoperative analgesia efficacy after endoscopic sinus surgery.
Each study blocked SPG with injection of different local anesthetics using different approaches. In 5 studies, SPG block was consistently found to be effective in reducing the need of analgesics after endoscopic sinus surgery. A combination with maxillary transcutaneous nerve block may be also helpful but further systematic study is necessary to evaluate its efficacy. Grade of recommendation is also B for reducing pain associated with nasal packing removal after 
Table 4 Studies of SPG block for trigeminal neuralgia

\begin{tabular}{|c|c|c|c|c|c|c|c|c|}
\hline \multicolumn{9}{|c|}{ Trigeminal neuralgia } \\
\hline Author & Year & Medical problems & Approach & Imaging & Medication & Number of cases & Study design & Outcome \\
\hline $\begin{array}{l}\text { Peterson } \\
\text { et al. [12] }\end{array}$ & 1995 & Trigeminal neuralgia & $\begin{array}{l}\text { Cotton tip } \\
\text { applicator }\end{array}$ & None & $4 \%$ lidocaine & 2 & Case series & Pain free \\
\hline $\begin{array}{l}\text { Manahan } \\
\text { et al. [13] }\end{array}$ & 1996 & Trigeminal neuralgia & NA & None & Bupivacaine & 1 & Case report & Pain free \\
\hline $\begin{array}{l}\text { Kanai } \\
\text { et al. [11] }\end{array}$ & 2006 & $\begin{array}{l}\text { Second division } \\
\text { trigeminal neuralgia }\end{array}$ & Nasal spray & None & Lidocaine & 25 & $\begin{array}{l}\text { Randomized } \\
\text { control }\end{array}$ & $\begin{array}{l}\text { Significantly decreased } \\
\text { pain with intranasal } \\
\text { lidocaine spray }\end{array}$ \\
\hline $\begin{array}{l}\text { Candido } \\
\text { et al. [14] }\end{array}$ & 2013 & $\begin{array}{l}\text { Trigeminal neuralgia, } \\
\text { chronic migraine } \\
\text { headache, } \\
\text { post-herpetic } \\
\text { neuralgia }\end{array}$ & $\begin{array}{l}\text { Tx360 Nasal } \\
\text { applicator, } \\
\text { transnasal }\end{array}$ & None & $\begin{array}{l}0.5 \% \text { ropivacaine } \\
\text { and } 2 \mathrm{mg} \\
\text { dexamethasone }\end{array}$ & 3 & Case series & Satisfactory \\
\hline
\end{tabular}

nasal surgery, using lidocaine injection through the infrazygomatic approach.

\section{Head and neck cancer pain}

Three case reports and series were found (level 4 evidence, Table 7). One study was SPG block and two on SPG neurolysis with phenol. The largest case series was by Varghese et al. [25], who reported 22 cases of successful treatment with $6 \%$ phenol used via nasal endoscopy, as a neurolytic sphenopalatine ganglion block, for pain caused by advanced head and neck cancer. The overall grade of recommendation is $\mathrm{C}$ for any of these painful conditions.

\section{Postherpetic neuralgia}

A total of three case reports and series were found through our search process (level 4 evidence, Table 8 ). All three articles reported successful treatment of postherpetic neuralgia with SPG block using local anesthetics. One study reported successful treatment of postherpetic neuralgia involving the ophthalmic division of the trigeminal nerve, by SPG block under direct visualization through nasal endoscopy [26]. Another article reported success in treating sinus arrest in postherpetic neuralgia by SPG block through trans-nasal approach utilizing cotton tipped applicators [27], and one study reported successful treatment of herpes zoster within a heterogeneous case series [28]. The overall grade of recommendation is $\mathrm{C}$.

\section{Musculoskeletal pain}

There were two negative randomized-controlled study on head, neck and shoulder myofascial pain. There were also a small case-control study on low back pain, a small randomized-controlled study on chronic muscle pain syndrome and two large case series in our literature search (Table 9).

Successful treatment of lumbosacral pain with SPG block was initially reported in two large case series in the 1940s [28, 29]. However, further randomizedcontrolled studies dismissed these findings. Scudds et al. [3] reported a randomized-controlled study applying

Table 5 Studies of SPG block for migraine

\begin{tabular}{|c|c|c|c|c|c|c|c|c|}
\hline \multicolumn{9}{|l|}{ Migraine } \\
\hline Author & Year & $\begin{array}{l}\text { Medical } \\
\text { problems }\end{array}$ & Approach & Imaging & Medication & $\begin{array}{l}\text { Number of } \\
\text { cases }\end{array}$ & Study design & Outcome \\
\hline $\begin{array}{l}\text { Amster } \\
\text { et al. [28] }\end{array}$ & 1948 & Migraine & $\begin{array}{l}\text { Cotton tipped } \\
\text { applicator, } \\
\text { transnasal } \\
\text { approach }\end{array}$ & None & $\begin{array}{l}\text { Nupercaine, } \\
\text { pontocaine, } \\
\text { monocaine }\end{array}$ & 4 & Case series & $\begin{array}{l}\text { Relief of pain and spasm in } \\
90 \% \text { of cases }\end{array}$ \\
\hline $\begin{array}{l}\text { Maizels } \\
\text { et al. [56] }\end{array}$ & 1999 & $\begin{array}{l}\text { Migraine } \\
\text { with aura }\end{array}$ & $\begin{array}{l}\text { Self-administered } \\
\text { intranasal } 4 \% \\
\text { lidocaine }\end{array}$ & None & 4\% lidocaine & 1 & Case report & $\begin{array}{l}\text { Most headaches were successfully } \\
\text { aborted for } 15 \text { months }\end{array}$ \\
\hline $\begin{array}{l}\text { Yarnitsky } \\
\text { et al. [57] }\end{array}$ & 2003 & Migraine & $\begin{array}{l}\text { Cotton tip } \\
\text { applicator }\end{array}$ & None & 2\% lidocaine & 32 & Case series & $\begin{array}{l}\text { Significant reduction in pain score } \\
\text { during migraine }\end{array}$ \\
\hline $\begin{array}{l}\text { Cady } \\
\text { et al. [15] }\end{array}$ & 2015 & $\begin{array}{l}\text { Chronic } \\
\text { migraine }\end{array}$ & Tx360 & None & 0.5\% bupivacaine & 38 & $\begin{array}{l}\text { Double blind, } \\
\text { placebo control }\end{array}$ & $\begin{array}{l}\text { Significantly decreased headache } \\
\text { at } 24 \mathrm{~h}\end{array}$ \\
\hline $\begin{array}{l}\text { Cady } \\
\text { et al. [16] }\end{array}$ & 2015 & $\begin{array}{l}\text { Chronic } \\
\text { migraine }\end{array}$ & T×360 & None & $0.5 \%$ bupivacaine & 38 & $\begin{array}{l}\text { Double blind, } \\
\text { placebo control }\end{array}$ & $\begin{array}{l}\text { No statistical difference at } 1 \text { month } \\
\text { and } 6 \text { months between treatment } \\
\text { and control groups. }\end{array}$ \\
\hline
\end{tabular}


Table 6 Studies of SPG blocks for operative pain of the head and face

\begin{tabular}{|c|c|c|c|c|c|c|c|c|}
\hline \multicolumn{9}{|c|}{ Operative Pain of the head and neck } \\
\hline Author & Year & Medical problems & Approach & Imaging & Medication & $\begin{array}{l}\text { Number } \\
\text { of cases }\end{array}$ & Study design & Outcome \\
\hline $\begin{array}{l}\text { Robiony } \\
\text { et al. [24] }\end{array}$ & 1998 & $\begin{array}{l}\text { Skeletal transverse } \\
\text { discrepancy of the } \\
\text { maxilla }\end{array}$ & $\begin{array}{l}\text { Transcutaneous truncal } \\
\text { anesthesia of the maxillary } \\
\text { nerve in association with } \\
\text { transmucosal anesthesia } \\
\text { of the sphenopalatine } \\
\text { ganglion }\end{array}$ & None & $\begin{array}{l}\text { Prilocaine } \\
\text { carbocaine } \\
\text { cream }\end{array}$ & 12 & Case series & $\begin{array}{l}\text { Total anesthesia } \\
\text { of the maxillary } \\
\text { area facilitated } \\
\text { the operations } \\
\text { and appreciably } \\
\text { reduced amount } \\
\text { of postoperative } \\
\text { pain }\end{array}$ \\
\hline $\begin{array}{l}\text { Hwang } \\
\text { et al. [23] }\end{array}$ & 2003 & $\begin{array}{l}\text { Removal of nasal } \\
\text { packing after nasal } \\
\text { operation }\end{array}$ & $\begin{array}{l}\text { Needle injection into the } \\
\text { greater palatine canal }\end{array}$ & None & $1 \%$ lidocaine & 11 & Case-control & $\begin{array}{l}\text { Injection side } \\
\text { had significantly } \\
\text { lower pain than } \\
\text { the control side }\end{array}$ \\
\hline $\begin{array}{l}\text { Ahmed } \\
\text { et al. [18] }\end{array}$ & 2007 & $\begin{array}{l}\text { Endoscopic sinonasal } \\
\text { surgery intraoperative } \\
\text { isofluorane consumption, } \\
\text { hypotensive agents used, } \\
\text { postoperative pain }\end{array}$ & $\begin{array}{l}\text { Bilateral SPG block, } \\
\text { injected between the } \\
\text { middle and inferior } \\
\text { turbinates }\end{array}$ & None & $\begin{array}{l}0.5 \% \text { lidocaine } \\
\text { and epinephrine. }\end{array}$ & $\begin{array}{l}15 \text { cases, } \\
15 \text { controls }\end{array}$ & $\begin{array}{l}\text { Randomized- } \\
\text { controlled }\end{array}$ & $\begin{array}{l}\text { Significantly } \\
\text { reduced } \\
\text { intraoperative } \\
\text { isofluorane } \\
\text { consumption } \\
\text { and esmolol } \\
\text { use, postoperative } \\
\text { tramadol use } \\
\text { and postoperative } \\
\text { pain. }\end{array}$ \\
\hline Ali et al. [20] & 2010 & $\begin{array}{l}\text { Endoscopic trans-nasal } \\
\text { resection of pituitary } \\
\text { adenoma, anesthetic, } \\
\text { vasodilator and analgesic } \\
\text { sparing effect }\end{array}$ & $\begin{array}{l}\text { Bilateral SPG block, } \\
\text { injected between } \\
\text { the middle and } \\
\text { inferior turbinates }\end{array}$ & None & $\begin{array}{l}\text { 1.5\% lidocaine } \\
\text { and epinephrine }\end{array}$ & $\begin{array}{l}15 \text { cases } \\
\text { and } \\
15 \text { controls }\end{array}$ & $\begin{array}{l}\text { Randomized- } \\
\text { controlled }\end{array}$ & $\begin{array}{l}\text { Significantly } \\
\text { reduced in } \\
\text { sevoflurane and } \\
\text { nitroglycerine } \\
\text { consumption, } \\
\text { emergence time, } \\
\text { postoperative } \\
\text { pain and need } \\
\text { of meperidine } \\
\text { analgesia. }\end{array}$ \\
\hline $\begin{array}{l}\text { Kesimci } \\
\text { et al. [22] }\end{array}$ & 2012 & $\begin{array}{l}\text { Endoscopic sinus surgery } \\
\text { postoperative analgesia } \\
\text { efficacy }\end{array}$ & $\begin{array}{l}\text { Bilateral SPG block, } \\
\text { injected between } \\
\text { the middle and } \\
\text { inferior turbinates }\end{array}$ & None & $\begin{array}{l}0.5 \% \\
\text { bupivacaine } \\
\text { or } 0.5 \% \\
\text { levobupivacaine }\end{array}$ & 45 & $\begin{array}{l}\text { Double-blind } \\
\text { randomized, } \\
\text { placebo- } \\
\text { controlled }\end{array}$ & $\begin{array}{l}\text { Postoperative } \\
\text { pain significantly } \\
\text { reduced, also } \\
\text { significantly few } \\
\text { patients requiring } \\
\text { additional } \\
\text { analgesics in the } \\
\text { postoperative } \\
24 \mathrm{~h} \text {. }\end{array}$ \\
\hline $\begin{array}{l}\text { Demaria } \\
\text { et al. [21] }\end{array}$ & 2012 & $\begin{array}{l}\text { Endoscopic sinus surgery } \\
\text { postoperative analgesia } \\
\text { efficacy }\end{array}$ & $\begin{array}{l}\text { Bilateral SPG block, } \\
\text { palatal approach }\end{array}$ & None & $\begin{array}{l}2 \% \text { lidocaine } \\
\text { and } 1 \% \\
\text { tetracaine }\end{array}$ & 70 & $\begin{array}{l}\text { Double-blind } \\
\text { randomized, } \\
\text { placebo- } \\
\text { controlled }\end{array}$ & $\begin{array}{l}\text { Patients were } \\
\text { discharged } \\
\text { sooner than the } \\
\text { control group. } \\
\text { The block group } \\
\text { also required less } \\
\text { total fentanyl in } \\
\text { the recovery } \\
\text { room. }\end{array}$ \\
\hline $\begin{array}{l}\text { Al-Qudah } \\
\text { et al. [19] }\end{array}$ & 2015 & $\begin{array}{l}\text { Endoscopic sinus surgery } \\
\text { postoperative analgesia } \\
\text { efficacy }\end{array}$ & $\begin{array}{l}\text { Applied to the SPG } \\
\text { region }\end{array}$ & None & $\begin{array}{l}2 \% \text { lidocaine } \\
\text { and epinephrine }\end{array}$ & $\begin{array}{l}60(30 \\
\text { cases, } 30 \\
\text { controls) }\end{array}$ & $\begin{array}{l}\text { Double- } \\
\text { blind, } \\
\text { placebo } \\
\text { controlled }\end{array}$ & $\begin{array}{l}\text { Significant pain } \\
\text { reduction in the } \\
\text { SPG block group }\end{array}$ \\
\hline
\end{tabular}

SPG block (cotton-tipped pledgelets with $4 \%$ lidocaine) to 42 participants with fibromyalgia and 19 participants with myofascial pain syndrome. He reported no statistical difference between treatment and placebo group in pain intensity, headache frequency, sensitivity to pressure, anxiety, depression, and sleep quality. Janzen et al. [30] reported a similar randomized-controlled study by applying SPG block with lidocaine spray. Forty-two participants with fibromyalgia and 19 with myofascial pain syndrome were included in his study. He again found not difference 
Table 7 Studies of SPG block for cancer pain

\begin{tabular}{|c|c|c|c|c|c|c|c|c|}
\hline \multicolumn{9}{|c|}{ Head and neck cancer pain } \\
\hline Author & Year & Medical problems & Approach & Imaging & Medication & $\begin{array}{l}\text { Number of } \\
\text { cases }\end{array}$ & Study design & Outcome \\
\hline $\begin{array}{l}\text { Prasanna } \\
\text { et al. [58] }\end{array}$ & 1993 & $\begin{array}{l}\text { Pain from carcinoma of the } \\
\text { tongue and floor of the mouth }\end{array}$ & Nasal sinuscope & None & $\begin{array}{l}0.25 \% \\
\text { bupivacaine }\end{array}$ & 10 & Case series & Immediate pain relief \\
\hline $\begin{array}{l}\text { Varghese } \\
\text { et al. [25] }\end{array}$ & 2001 & $\begin{array}{l}\text { Pain due to advanced head } \\
\text { and neck cancer }\end{array}$ & $\begin{array}{l}\text { Endoscopic needle } \\
\text { injection }\end{array}$ & None & 6\% phenol & 22 & Case series & $\begin{array}{l}17 \text { out of } 22 \text { patients } \\
\text { had significant pain } \\
\text { relief }\end{array}$ \\
\hline $\begin{array}{l}\text { Varghese } \\
\text { el al. [59] }\end{array}$ & 2002 & $\begin{array}{l}\text { Pain due to advanced head } \\
\text { and neck cancer }\end{array}$ & $\begin{array}{l}\text { Transnasal through the } \\
\text { sphenopalatine foramen }\end{array}$ & None & $6 \%$ phenol & 1 & Case report & Significant pain relief \\
\hline
\end{tabular}

between the treatment and placebo group. Ferrante et al. [31] reported a randomized-controlled study with 13 cases of head, neck and shoulder myofascial pain and 7 healthy controls. He also showed no significant effect with SPG block. On low back pain, Berger et al. [32] reported a case-control study with 21 patients randomized to cocaine, lidocaine and saline. He did not find significant differences in outcomes. Given the negative randomizedcontrolled studies, it is not recommended to use SPG block on musculoskeletal pain.

\section{Postdural puncture headache}

There were two case series and one case report (level 4) reporting successful treatment of postdural puncture headache (Table 10). No higher-level studies were available. Cohen et al. [33] reported the largest case series of 32 cases with postdural puncture headache. In the series, $69 \%$ of the patients treated with transnasal SPG block were saved from epidural blood patch. The overall grade of recommendation is C for SPG block on postdural puncture headache.

\section{Other pain syndromes of the head and face}

Pain syndromes involving the head and face not belonging to any category mentioned above are summarized in Table 11. There was a negative randomized-controlled study using Tx360 device treating acute anterior and global headache [34]. There were also multiple case reports and series on the effectiveness of SPG in controlling various types of head and facial pain. Local anesthetics and steroids have been used for SPG block, while phenol and alcohol have been used for SPG neurolysis. They have been successfully used in Sluder's neuralgia, sphenopalatine maxillary neuralgia, facial neuralgia, sympathetic neuralgia, post-traumatic atypical facial pain, atypical odontalgia, pain from midline granuloma, herpetic keratitis, hemifacial headache, paroxysmal hemicrania, nasal pain, hemicrania continua and trigeminal neuropathy. The largest case series was provided by Rodman et al. [35], documenting 147 patients with various types of nasal pain and headache. He reported that $81.3 \%$ of the patients had pain relief after receiving SPG block with a mixture of bupivacaine and triamcinolone. Schaffer et al. [34] reported a randomized placebocontrolled study using Tx360 device to treat acute anterior or global headache. A total of 93 participants were recruited in the study, but the study showed no statistical significance between the treatment and control groups. Because of the result, we do not recommend SPG block for anterior or global headache. The overall grade of recommendation is $\mathrm{C}$ for other types of head and facial pain, including Sluder's neuralgia, sphenopalatine maxillary neuralgia, facial neuralgia, sympathetic neuralgia, post-traumatic atypical facial pain, atypical

Table 8 Studies of SPG block on postherpetic neuralgia

\begin{tabular}{|c|c|c|c|c|c|c|c|c|}
\hline \multicolumn{9}{|c|}{ Postherpetic neuralgia } \\
\hline Author & Year & Medical problems & Approach & Imaging & Medication & $\begin{array}{l}\text { Number } \\
\text { of cases }\end{array}$ & $\begin{array}{l}\text { Study } \\
\text { design }\end{array}$ & Outcome \\
\hline $\begin{array}{l}\text { Prasanna } \\
\text { et al. [26] }\end{array}$ & 1993 & $\begin{array}{l}\text { Postherpetic neuralgia } \\
\text { involving the ophthalmic } \\
\text { division of the trigeminal } \\
\text { nerve }\end{array}$ & $\begin{array}{l}\text { Combination of stellate } \\
\text { ganglion and sphenopalatine } \\
\text { ganglion block, cotton } \\
\text { tip applicator }\end{array}$ & None & $\begin{array}{l}\text { Lidocaine and } \\
\text { bupivacaine }\end{array}$ & 1 & Case report & Pain free \\
\hline $\begin{array}{l}\text { Saberski } \\
\text { et al. [27] }\end{array}$ & 1999 & $\begin{array}{l}\text { Sinus arrest in } \\
\text { postherpetic neuralgia }\end{array}$ & $\begin{array}{l}\text { Cotton tipped applicator, } \\
\text { transnasal approach }\end{array}$ & None & $20 \%$ lidocaine & 1 & Case report & $\begin{array}{l}\text { No paroxysmal pain } \\
\text { or sinus pauses } \\
\text { immediately } \\
\text { after block }\end{array}$ \\
\hline $\begin{array}{l}\text { Amster } \\
\text { et al. [28] }\end{array}$ & 1948 & Herpes zoster & $\begin{array}{l}\text { Cotton tipped applicator, } \\
\text { transnasal approach }\end{array}$ & None & $\begin{array}{l}\text { Nupercaine, } \\
\text { pontocaine, } \\
\text { monocaine }\end{array}$ & 3 & Case series & $\begin{array}{l}\text { Relief of pain and } \\
\text { spasm in } 90 \% \text { of } \\
\text { cases }\end{array}$ \\
\hline
\end{tabular}


Table 9 Studies of SPG block for musculoskeletal pain

\begin{tabular}{|c|c|c|c|c|c|c|c|c|}
\hline \multicolumn{9}{|c|}{ Musculoskeletal pain } \\
\hline Author & Year & Medical problems & Approach & Imaging & Medication & Number of cases & Study design & Outcome \\
\hline $\begin{array}{l}\text { Amster } \\
\text { et al. [28] }\end{array}$ & 1948 & $\begin{array}{l}\text { Lumbosacral and } \\
\text { sacroiliac pain }\end{array}$ & $\begin{array}{l}\text { Cotton tipped } \\
\text { applicator, } \\
\text { transnasal } \\
\text { approach }\end{array}$ & None & $\begin{array}{l}\text { Nupercaine, } \\
\text { pontocaine, } \\
\text { monocaine }\end{array}$ & 61 & Case series & $\begin{array}{l}\text { Relief of pain and spasm in } \\
90 \% \text { of cases }\end{array}$ \\
\hline $\begin{array}{l}\text { Ruskin } \\
\text { et al. [29] }\end{array}$ & 1946 & $\begin{array}{l}\text { Lumbo-sacral } \\
\text { spasm }\end{array}$ & Unknown & None & $\begin{array}{l}\text { Cocaine, } \\
\text { novocaine } \\
\text { or nupercaine }\end{array}$ & 36 & Case series & $\begin{array}{l}\text { Pain partially or completely } \\
\text { relieved with SPGB and } \\
\text { intramuscular injections of } \\
\text { ironyl and calcium ascorbate }\end{array}$ \\
\hline $\begin{array}{l}\text { Berger } \\
\text { et al. [32] }\end{array}$ & 1986 & Low back pain & $\begin{array}{l}\text { Cotton tip } \\
\text { applicator and } \\
\text { transnasal needle }\end{array}$ & None & $\begin{array}{l}\text { Cocaine or } \\
\text { lidocaine }\end{array}$ & $\begin{array}{l}7 \text { cases with } \\
\text { cocaine, } 7 \text { cases } \\
\text { with lidocaine, } \\
7 \text { controls }\end{array}$ & Case-control & $\begin{array}{l}\text { No statistical significance } \\
\text { between cases and controls }\end{array}$ \\
\hline $\begin{array}{l}\text { Scudds } \\
\text { et al. [3] }\end{array}$ & 1995 & $\begin{array}{l}\text { Chronic muscle } \\
\text { pain syndrome }\end{array}$ & $\begin{array}{l}\text { Cotton tipped } \\
\text { applicator, } \\
\text { transnasal } \\
\text { approach }\end{array}$ & None & $4 \%$ lidocaine & $\begin{array}{l}42 \text { with } \\
\text { fibromyalgia, } \\
19 \text { with myofascial } \\
\text { pain syndrome }\end{array}$ & $\begin{array}{l}\text { Double-blind } \\
\text { randomized } \\
\text { controlled }\end{array}$ & $\begin{array}{l}\text { No statistical significance } \\
\text { between } 4 \% \text { lidocaine and } \\
\text { placebo }\end{array}$ \\
\hline $\begin{array}{l}\text { Janzen } \\
\text { et al. [30] }\end{array}$ & 1997 & $\begin{array}{l}\text { Myofascial pain } \\
\text { syndrome and } \\
\text { fibromyalgia }\end{array}$ & Nasal spray & None & 4\% lidocaine & $\begin{array}{l}42 \text { with fibromyalgia, } \\
19 \text { with myofascial } \\
\text { pain syndrome }\end{array}$ & $\begin{array}{l}\text { Double-blind, } \\
\text { placebo- } \\
\text { controlled }\end{array}$ & $\begin{array}{l}\text { No statistical significance } \\
\text { between } 4 \% \text { lidocaine and } \\
\text { placebo }\end{array}$ \\
\hline $\begin{array}{l}\text { Ferrante } \\
\text { et al. [31] }\end{array}$ & 1998 & $\begin{array}{l}\text { Myofascial pain } \\
\text { syndrome of the } \\
\text { head, neck and } \\
\text { shoulders }\end{array}$ & NA & None & 4\% lidocaine & $\begin{array}{l}13 \text { cases, } \\
7 \text { controls }\end{array}$ & $\begin{array}{l}\text { Double-blind, } \\
\text { placebo- } \\
\text { controlled, } \\
\text { crossover } \\
\text { design }\end{array}$ & No statistical significance \\
\hline
\end{tabular}

odontalgia, pain from midline granuloma, herpetic keratitis, hemifacial headache, paroxysmal hemicrania, nasal pain, hemicrania continua and trigeminal neuropathy.

\section{Other syndromes}

SPG block has been used for a myriad of other conditions not involved in painful syndromes of the head and face. These conditions include seizures associated nasal pathology, arthritic pain and muscle spasm, intercostal neuritis, persistent hiccups, ureteral colic, dysmenorrhea, peripheral painful vascular spasm, complex regional pain syndrome and hypertension (Table 12). Most of these studies reported significant improvement, but none of them had evidence level above case series. There was one randomized-controlled study in assessing the efficacy of SPG block in treating nicotine addiction, but the result was negative [36]. One small double-blind cross-over study examined whether SPG block reduces experimentally induced pain using submaximal effort tourniquet test, but the SPG block failed to make a difference in pain perception [37].

Overall, the grade of recommendation for any of these syndrome remains at C. SPG block is not recommended for nicotine addiction due to the negative randomized study.

\section{Summary for SPG block}

Grade of recommendation of using SPG block is B for cluster headache, second-division trigeminal neuralgia, migraine, reducing the pain associated with nasal packing removal after nasal operation and for reducing the needs of analgesics after endoscopic sinus surgery. Out of these conditions, SPG block has the best evidence in reducing the needs of analgesics after endoscopic sinus surgery, as there are six randomized-controlled studies. It should be noted that the recommendation for cluster

Table 10 Studies of SPG blocks for postdural puncture headache

\begin{tabular}{|c|c|c|c|c|c|c|c|c|}
\hline \multicolumn{9}{|c|}{ Postdural puncture headache } \\
\hline Author & Year & Medical problems & Approach & Imaging & Medication & $\begin{array}{l}\text { Number } \\
\text { of cases }\end{array}$ & $\begin{array}{l}\text { Study } \\
\text { design }\end{array}$ & Outcome \\
\hline Cohen et al. [60] & 2014 & $\begin{array}{l}\text { Postdural puncture } \\
\text { headache }\end{array}$ & $\begin{array}{l}\text { Cotton-tip } \\
\text { applicator }\end{array}$ & None & $5 \%$ lidocaine & 32 & Case series & $\begin{array}{l}69 \% \text { of the patients were saved } \\
\text { from epidural blood patch }\end{array}$ \\
\hline Kent et al. [4] & 2015 & $\begin{array}{l}\text { Postdural puncture } \\
\text { headache }\end{array}$ & $\begin{array}{l}\text { Cotton-tip } \\
\text { applicator }\end{array}$ & None & $2 \%$ lidocaine & 3 & Case series & $\begin{array}{l}1 \text { patient had relief, } 2 \text { had to get } \\
\text { epidural blood patch. }\end{array}$ \\
\hline Cardoso et al. [61] & 2017 & $\begin{array}{l}\text { Postdural puncture } \\
\text { headache }\end{array}$ & $\begin{array}{l}\text { Cotton-tip } \\
\text { applicator }\end{array}$ & None & 0.5\% Levobupivacaine & 1 & Case report & Symptoms relieved by 5 min. \\
\hline
\end{tabular}


Table 11 Studies of SPG blocks for other pain syndromes of the head and face

\begin{tabular}{|c|c|c|c|c|c|c|c|c|}
\hline \multicolumn{9}{|c|}{ Pain syndromes of the head and face } \\
\hline Author & Year & $\begin{array}{l}\text { Medical } \\
\text { problems }\end{array}$ & Approach & Imaging & Medication & $\begin{array}{l}\text { Number } \\
\text { of cases }\end{array}$ & Study design & Outcome \\
\hline Ruskin et al. [62] & 1925 & $\begin{array}{l}\text { SP maxillary neuralgia, } \\
\text { SP facial neuralgia, } \\
\text { SP sympathetic neuralgia, } \\
\text { SPG cell neuralgia }\end{array}$ & Needle injection. & None & $\begin{array}{l}\text { 20\% Cocaine, } \\
10 \% \text { silver nitrate, } \\
70 \% \text { alcohol }\end{array}$ & 7 & Case series & $\begin{array}{l}\text { Improvements } \\
\text { or complete } \\
\text { relief }\end{array}$ \\
\hline Stechison et al. [63] & 1994 & $\begin{array}{l}\text { Post-traumatic atypical } \\
\text { facial pain syndrome }\end{array}$ & $\begin{array}{l}\text { Needle injection. } \\
\text { Transfacial } \\
\text { transpterygomaxillary } \\
\text { access to foramen } \\
\text { rotundum SPG and } \\
\text { maxillary nerve }\end{array}$ & CT & $\begin{array}{l}\text { First stage: } 0.5 \% \\
\text { bupivacaine, } \\
\text { Second stage: } 98 \% \\
\text { ethyl alcohol and } \\
0.5 \% \text { bupivacaine } \\
\text { in } 2: 1 \text { ratio }\end{array}$ & 5 & Case series & $\begin{array}{l}3 \text { had alcohol } \\
\text { neurotomy } \\
\text { and pain free } \\
\text { at } 5,8 \text { and } \\
12 \text { months. } \\
2 \text { responded } \\
\text { poorly to first } \\
\text { stage blockade } \\
\text { and did not } \\
\text { have alcohol } \\
\text { neurotomy. }\end{array}$ \\
\hline Peterson et al. [12] & 1995 & Atypical odontalgia & $\begin{array}{l}\text { Cotton tip, } \\
\text { self-application }\end{array}$ & None & $4 \%$ lidocaine & 1 & Case report & Pain free \\
\hline Saade et al. [64] & 1996 & $\begin{array}{l}\text { Pain from midline } \\
\text { granuloma }\end{array}$ & $\begin{array}{l}\text { Self-administered } \\
\text { SPG block }\end{array}$ & None & Lidocaine & 1 & Case report & $\begin{array}{l}\text { Significant } \\
\text { pain relief }\end{array}$ \\
\hline Puig et al. [65] & 1998 & Sluder's neuralgia & $\begin{array}{l}\text { Cotton tip } \\
\text { applicator and } \\
\text { transnasal needle }\end{array}$ & None & $88 \%$ phenol & 8 & Case series & $\begin{array}{l}90 \% \text { decrease } \\
\text { in head and } \\
\text { face pain for } \\
9.5 \text {-month } \\
\text { duration }\end{array}$ \\
\hline Windsor et al. [66] & 2004 & Herpetic keratitis & $\begin{array}{l}\text { Transnasal cotton } \\
\text { tip applicator }\end{array}$ & None & $\begin{array}{l}\text { Tetracaine, } \\
\text { adrenalin and } \\
10 \% \text { cocaine] }\end{array}$ & 1 & Case report & $\begin{array}{l}\text { Effect of block } \\
\text { lasts for a } \\
\text { month. Requires } \\
\text { months blocks }\end{array}$ \\
\hline Obah et al. [67] & 2006 & Hemifacial and headache & Transnasal & None & $4 \%$ lidocaine & 1 & Case report & $\begin{array}{l}80 \% \text { reduction } \\
\text { in pain } \\
\text { intensity }\end{array}$ \\
\hline Cohen et al. [33] & 2009 & $\begin{array}{l}\text { Postdural puncture } \\
\text { headache }\end{array}$ & $\begin{array}{l}\text { Cotton tip } \\
\text { applicator }\end{array}$ & None & Lignocaine & 13 & Case series & $\begin{array}{l}11 \text { out of } 13 \\
\text { had immediate } \\
\text { relief of } \\
\text { headache }\end{array}$ \\
\hline Morelli et al. [68] & 2010 & $\begin{array}{l}\text { Paroxysmal hemicrania } \\
\text { resistant to multiple } \\
\text { therapies }\end{array}$ & $\begin{array}{l}\text { Endoscopic needle } \\
\text { injection into the } \\
\text { nasal mucous } \\
\text { membrane } \\
\text { immediately } \\
\text { behind and over } \\
\text { the inferior portion } \\
\text { of the sphenopalatine } \\
\text { foramen and into } \\
\text { the fossa }\end{array}$ & None & $\begin{array}{l}\text { Triamcinolone } \\
\text { acetonide, } \\
1 \% \text { bupivacaine, } \\
2 \% \text { mepivacaine } \\
\text { with adrenalin }\end{array}$ & 1 & Case report & $\begin{array}{l}\text { Reduction in } \\
\text { frequency } \\
\text { and intensity } \\
\text { of pain }\end{array}$ \\
\hline Rodman et al. [35] & 2012 & Nasal pain or headache & $\begin{array}{l}\text { Endoscopic needle } \\
\text { injection }\end{array}$ & None & $\begin{array}{l}0.5 \% \text { bupivacaine } \\
\text { and triamcinolone } \\
\text { acetonide }\end{array}$ & 147 & Case series & $\begin{array}{l}81.3 \% \text { of patients } \\
\text { have improvement }\end{array}$ \\
\hline Grant et al. [69] & 2014 & $\begin{array}{l}\text { Tension headache in } \\
\text { pregnant woman }\end{array}$ & $\begin{array}{l}\text { Cotton tip } \\
\text { applicator }\end{array}$ & None & $4 \%$ lidocaine & 1 & Case report & $\begin{array}{l}\text { BID block for } \\
\text { a total of } 7 \\
\text { blocks, pain } \\
\text { free after }\end{array}$ \\
\hline Kastler et al. [55] & 2014 & $\begin{array}{l}\text { Cluster headache (14), } \\
\text { persistent idiopathic } \\
\text { facial pain (10), and } \\
\text { other types of facial } \\
\text { pain (18) }\end{array}$ & $\begin{array}{l}\text { Infrazygomatic } \\
\text { approach }\end{array}$ & CT & Absolute alcohol & 28 & Case series & $\begin{array}{l}85.7 \% \text { of } \\
\text { patient with } \\
\text { persistent } \\
\text { idiopathic } \\
\text { facial pain } \\
\text { and } 40 \% \text { of } \\
\text { other types } \\
\text { of facial pain } \\
\text { had } 50 \% \\
\text { pain relief } \\
\text { at } 1 \text { month }\end{array}$ \\
\hline
\end{tabular}


Table 11 Studies of SPG blocks for other pain syndromes of the head and face (Continued)

\begin{tabular}{|c|c|c|c|c|c|c|c|c|}
\hline \multicolumn{9}{|c|}{ Pain syndromes of the head and face } \\
\hline Author & Year & $\begin{array}{l}\text { Medical } \\
\text { problems }\end{array}$ & Approach & Imaging & Medication & $\begin{array}{l}\text { Number } \\
\text { of cases }\end{array}$ & Study design & Outcome \\
\hline $\begin{array}{l}\text { Androulakis } \\
\text { et al. [70] }\end{array}$ & 2016 & $\begin{array}{l}\text { Hemicrania } \\
\text { continua }\end{array}$ & T×360 device & None & $\begin{array}{l}\text { Repetitive } 0.5 \% \\
\text { bupivacaine }\end{array}$ & 1 & Case report & $\begin{array}{l}\text { Significant } \\
\text { improvement } \\
\text { in headache } \\
\text { by } 14 \text { week }\end{array}$ \\
\hline $\begin{array}{l}\text { Malec-Milewska } \\
\text { et al. [71] }\end{array}$ & 2015 & $\begin{array}{l}\text { Trigeminal } \\
\text { neuropathy }\end{array}$ & $\begin{array}{l}\text { Zygomatic } \\
\text { approach }\end{array}$ & Fluoroscopy & $\begin{array}{l}65 \% \text { ethanol } \\
\text { with lidocaine }\end{array}$ & 20 & Case series & $\begin{array}{l}\text { Significant } \\
\text { pain relief }\end{array}$ \\
\hline Schaffer [34] & 2015 & $\begin{array}{l}\text { Acute anterior or global } \\
\text { headache }\end{array}$ & Tx360 device & None & $0.5 \%$ bupivacaine & 93 & $\begin{array}{l}\text { Randomized } \\
\text { placebo- } \\
\text { controlled }\end{array}$ & $\begin{array}{l}\text { No statistically } \\
\text { significant } \\
\text { difference }\end{array}$ \\
\hline Sussman et al. [72] & 2016 & $\begin{array}{l}\text { Chronic posttraumatic } \\
\text { headache after sport- } \\
\text { related concussion }\end{array}$ & Cotton-tip applicator & None & $\begin{array}{l}2 \% \text { lidocaine and } \\
0.5 \% \text { bupivacaine }\end{array}$ & 1 & Case report & $\begin{array}{l}\text { Symptom free at } \\
6 \text {-month follow-up }\end{array}$ \\
\hline
\end{tabular}

headache, second-division trigeminal neuralgia and migraine are each based on one small study, and it is only meant for acute treatment. There is no positive controlled study warranting chronic treatment with SPG block. For other pain syndromes, grade of recommendations is $\mathrm{C}$ due to the lack of positive controlled studies. These syndromes include postdural puncture headache, sphenopalatine maxillary neuralgia, facial neuralgia, sympathetic neuralgia, post-traumatic atypical facial pain, atypical odontalgia, pain from midline granuloma, herpetic keratitis, hemifacial headache, paroxysmal hemicrania, nasal pain, hemicrania continua, trigeminal neuropathy, cancer pain, seizures associated nasal pathology, arthritic pain and muscle spasm, intercostal neuritis, persistent hiccups, ureteral colic, dysmenorrhea, peripheral painful vascular spasm, complex regional pain syndrome and hypertension. Use of SPG block for myofascial pain, including fibromyalgia and head, neck, shoulder myofascial pain and low back pain, is not recommended due to several negative randomized-controlled studies.

\section{Radiofrequency ablation}

Fifteen studies were included on the topic of SPG radiofrequency ablation. One study was a small but positive prospective cohort study for cluster headaches, while the other 14 studies were case reports and case series. There were no controlled studies.

\section{Cluster headache}

There was one prospective cohort study and eight case reports/series on the treatment of cluster headache. Three case reports were on pulsed radiofrequency and six on continuous radiofrequency ablation (Table 13). Narouze et al. [38] performed a prospective cohort study of 15 cases of chronic cluster headaches treated with radiofrequency ablation using infrazygomatic approach under fluoroscopy guidance. A total of $0.5 \mathrm{~mL}$ of lidocaine $2 \%$ was injected and 2 radiofrequency lesions were carried out at $80{ }^{\circ} \mathrm{C}$ for $60 \mathrm{~s}$ each. After the ablation,
$0.5 \mathrm{~mL}$ of bupivacaine $0.5 \%$ and $5 \mathrm{mg}$ of triamcinolone were injected. He reported statistically improved attack intensity, frequency and pain disability index up to 18 months (level 2b). As for side effects: 50\% (7/15) reported temporary paresthesias in the upper gums and cheek that lasted for 3-6 weeks with complete resolution. In only one patient, a coin-like area of permanent anesthesia over the cheek persisted. Sanders et al. [39] reported the largest case series of 66 cluster headache patients treated with radiofrequency ablation after 12 to 70 months. He reported complete relief in $60.7 \%$ of patients with episodic cluster headache, and in $30 \%$ of patients with chronic cluster headache. Of the 66 treated patients, eight patients experienced temporary postoperative epistaxis and 11 patients exhibited cheek hematomas. A partial radiofrequency lesion of the maxillary nerve was inadvertently made in four patients. Nine patients complained of hypoesthesia of the palate, which disappeared in all patients within 3 months.

The grade of recommendation is B for treating cluster headache with radiofrequency ablation because of the positive cohort study.

\section{Other head and facial pain}

There were Seven case reports/series on various head and facial pain other than cluster headaches (all level 4, Table 14). These included Sluder's neuralgia, posttraumatic headache, chronic head and facial pain, atypical trigeminal neuralgia, atypical facial pain, chronic facial pain secondary to cavernous sinus meningioma, trigeminal neuralgia and SPG neuralgia due to herpes zoster. Akbas et al. [40] reported a 27-case series with various types of head and facial pain. In 35\% of the cases, pain was completely relieved, while $42 \%$ had moderate relief and 23\% had no relief with the SPG radiofrequency ablation. Because there were only case reports and case series available, the grade recommendation is $\mathrm{C}$ for any of these conditions. 
Table 12 Studies of SPG blocks for other syndromes

\begin{tabular}{|c|c|c|c|c|c|c|c|c|}
\hline \multicolumn{9}{|l|}{ Other syndromes } \\
\hline Author & Year & Medical problems & Approach & Imaging & Medication & $\begin{array}{l}\text { Number of } \\
\text { cases }\end{array}$ & $\begin{array}{l}\text { Study } \\
\text { design }\end{array}$ & Outcome \\
\hline Byrd et al. [73] & 1930 & "Remote dysfunctions" & $\begin{array}{l}\text { Cotton tipped } \\
\text { applicator, } \\
\text { transnasal } \\
\text { approach }\end{array}$ & None & $50 \%$ butyn & $\begin{array}{l}\text { Over } 2000 \\
\text { cases }\end{array}$ & Case series & $\begin{array}{l}\text { Remote } \\
\text { dysfunctions } \\
\text { were arrested }\end{array}$ \\
\hline Sparer et al. [74] & 1935 & $\begin{array}{l}\text { Recurrent convulsive } \\
\text { seizures associated } \\
\text { with nasal pathology }\end{array}$ & $\begin{array}{l}\text { Needle } \\
\text { injection }\end{array}$ & None & $\begin{array}{l}\text { Mixture of } \\
\text { alcohol and } \\
\text { novocaine }\end{array}$ & 3 & Case series & $\begin{array}{l}\text { Cessation of } \\
\text { seizures }\end{array}$ \\
\hline Ruskin et al. [29] & 1946 & $\begin{array}{l}\text { Muscle spasms and } \\
\text { arthritic pain }\end{array}$ & Unknown & None & $\begin{array}{l}\text { cocaine, } \\
\text { novocaine } \\
\text { or nupercaine }\end{array}$ & 68 & Case series & $\begin{array}{l}\text { Pain partially } \\
\text { or completely } \\
\text { relieved with } \\
\text { SPGB and } \\
\text { intramuscular } \\
\text { injections of } \\
\text { ironyl and } \\
\text { calcium } \\
\text { ascorbate }\end{array}$ \\
\hline Amster et al. [28] & 1948 & $\begin{array}{l}4 \text { migraine, } 2 \text { acute torticollis, } \\
12 \text { painful spastic shoulder, } \\
2 \text { intercostal neuritis, } \\
3 \text { herpes zosters, } \\
4 \text { persistent hiccups, } \\
5 \text { ureteral colic, } \\
3 \text { dysmenorrhea, } \\
7 \text { peripheral painful } \\
\text { vascular spasm, } \\
61 \text { lumbosacral } \\
\text { and sacroiliac pain }\end{array}$ & $\begin{array}{l}\text { Cotton tipped } \\
\text { applicator, } \\
\text { transnasal } \\
\text { approach }\end{array}$ & None & $\begin{array}{l}\text { Nupercaine, } \\
\text { pontocaine, } \\
\text { monocaine }\end{array}$ & 103 & Case series & $\begin{array}{l}\text { Relief of pain } \\
\text { and spasm in } \\
90 \% \text { of cases }\end{array}$ \\
\hline Ruskin et al. [75] & 1949 & Arthritic pain & Unknown & None & Unknown & 30 & Case series & $\begin{array}{l}\text { Pain partially } \\
\text { or completely } \\
\text { relieved with } \\
\text { SPGB and iron } \\
\text { salt of the } \\
\text { adenylic } \\
\text { nucleotide }\end{array}$ \\
\hline Slade et al. [51] & 1986 & $\begin{array}{l}\text { Tear secretion with } \\
\text { topical anesthesia }\end{array}$ & $\begin{array}{l}\text { Needle injection, } \\
\text { through the } \\
\text { greater palatine } \\
\text { foramen }\end{array}$ & None & $2 \%$ lidocaine & 10 & $\begin{array}{l}\text { Case-control } \\
\text { (using self } \\
\text { as control) }\end{array}$ & $\begin{array}{l}\text { Tear secretion } \\
\text { significantly } \\
\text { reduced by } \\
73 \%(p<0.001)\end{array}$ \\
\hline $\begin{array}{l}\text { Henneberger } \\
\text { et al. [36] }\end{array}$ & 1988 & Nicotine addiction & $\begin{array}{l}\text { Cotton tipped } \\
\text { applicator, } \\
\text { transnasal } \\
\text { approach }\end{array}$ & None & $\begin{array}{l}\text { Bupivacaine, } \\
\text { cocaine or } \\
\text { saline }\end{array}$ & $\begin{array}{l}6 \text { with } \\
\text { bupivacaine, } \\
5 \text { with cocaine, } \\
6 \text { with saline }\end{array}$ & $\begin{array}{l}\text { Double-blind } \\
\text { placebo- } \\
\text { controlled }\end{array}$ & $\begin{array}{l}\text { Significantly } \\
\text { fewer symptoms } \\
\text { of discomfort } \\
\text { for patients in } \\
\text { the anesthetic } \\
\text { treatment } \\
\text { groups than the } \\
\text { placebo group }\end{array}$ \\
\hline $\begin{array}{l}\text { Silverman } \\
\text { et al. [37] }\end{array}$ & 1993 & $\begin{array}{l}\text { Experimentally induced } \\
\text { pain (submaximal effort } \\
\text { tourniquet test) }\end{array}$ & $\begin{array}{l}\text { Cotton tipped } \\
\text { applicator }\end{array}$ & None & $\begin{array}{l}\text { 20\% lidocaine } \\
\text { and epinephrine }\end{array}$ & $\begin{array}{l}16 \text { healthy } \\
\text { volunteers }\end{array}$ & $\begin{array}{l}\text { Double-blind, } \\
\text { cross-over } \\
\text { study }\end{array}$ & $\begin{array}{l}\text { No significant } \\
\text { difference } \\
\text { between } \\
\text { experimental } \\
\text { and placebo } \\
\text { groups }\end{array}$ \\
\hline $\begin{array}{l}\text { Quevedo } \\
\text { et al. [76] }\end{array}$ & 2005 & $\begin{array}{l}\text { Complex regional pain } \\
\text { syndrome involving the } \\
\text { lower extremity }\end{array}$ & $\begin{array}{l}\text { Cotton tip } \\
\text { applicator, } \\
\text { transnasal }\end{array}$ & None & $4 \%$ tetracaine & 2 & Case series & $\begin{array}{l}50 \% \text { pain } \\
\text { reduction }\end{array}$ \\
\hline $\begin{array}{l}\text { Triantafyllidi } \\
\text { et al. [77] }\end{array}$ & 2016 & Hypertension & $\begin{array}{l}\text { Cotton tip } \\
\text { applicator, } \\
\text { transnasal }\end{array}$ & None & $2 \%$ lidocaine & 22 & Cohort study & $\begin{array}{l}\text { Systolic blood } \\
\text { pressure } \\
\text { significantly } \\
\text { decreased by } \\
24 \text { hrs and by } \\
21-30 \text { days }\end{array}$ \\
\hline
\end{tabular}




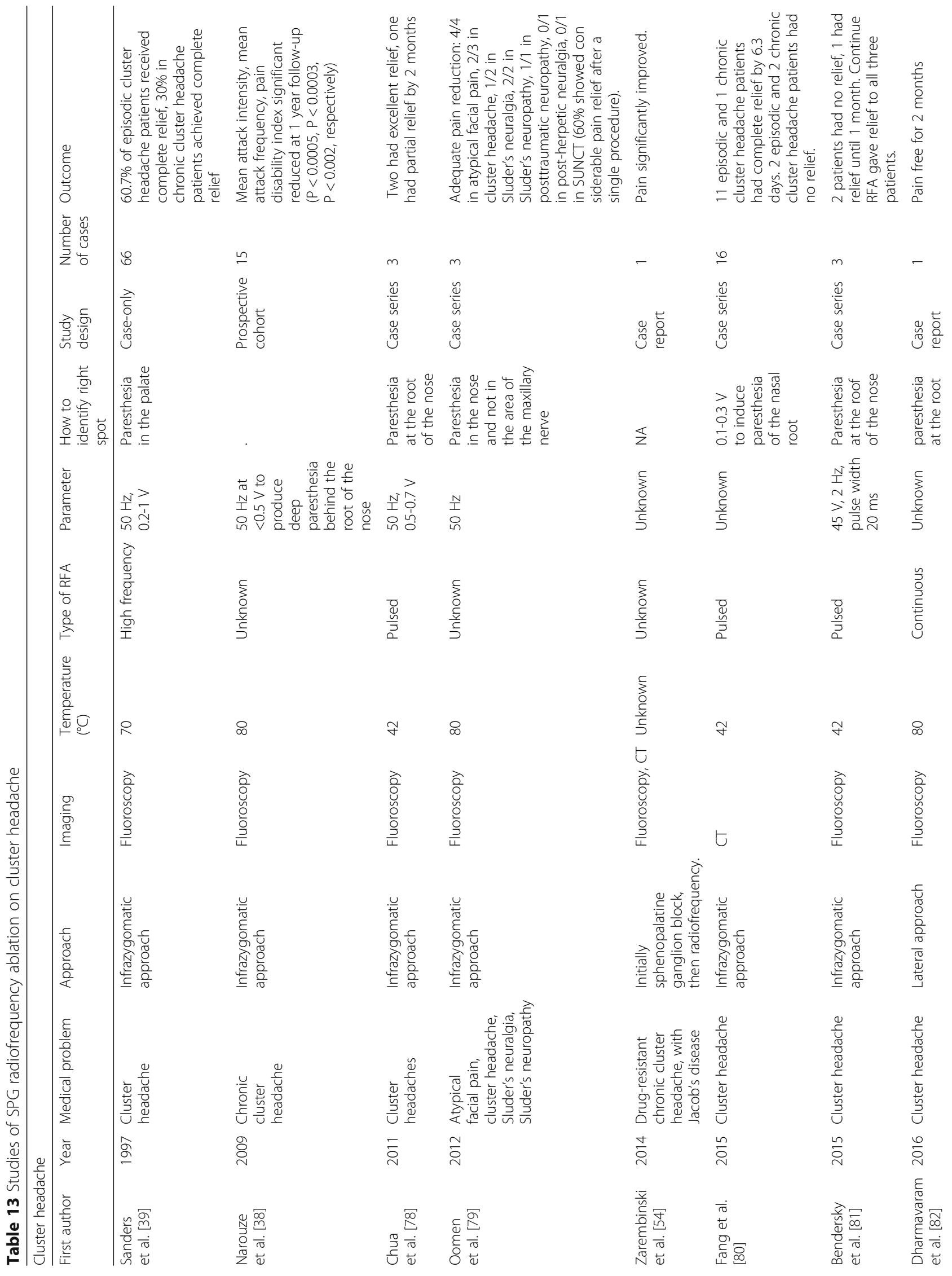




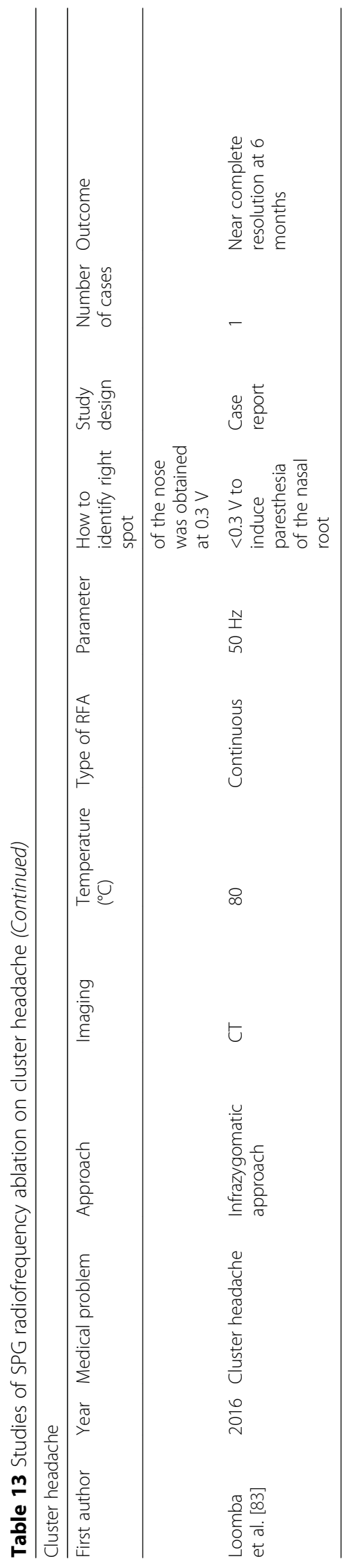




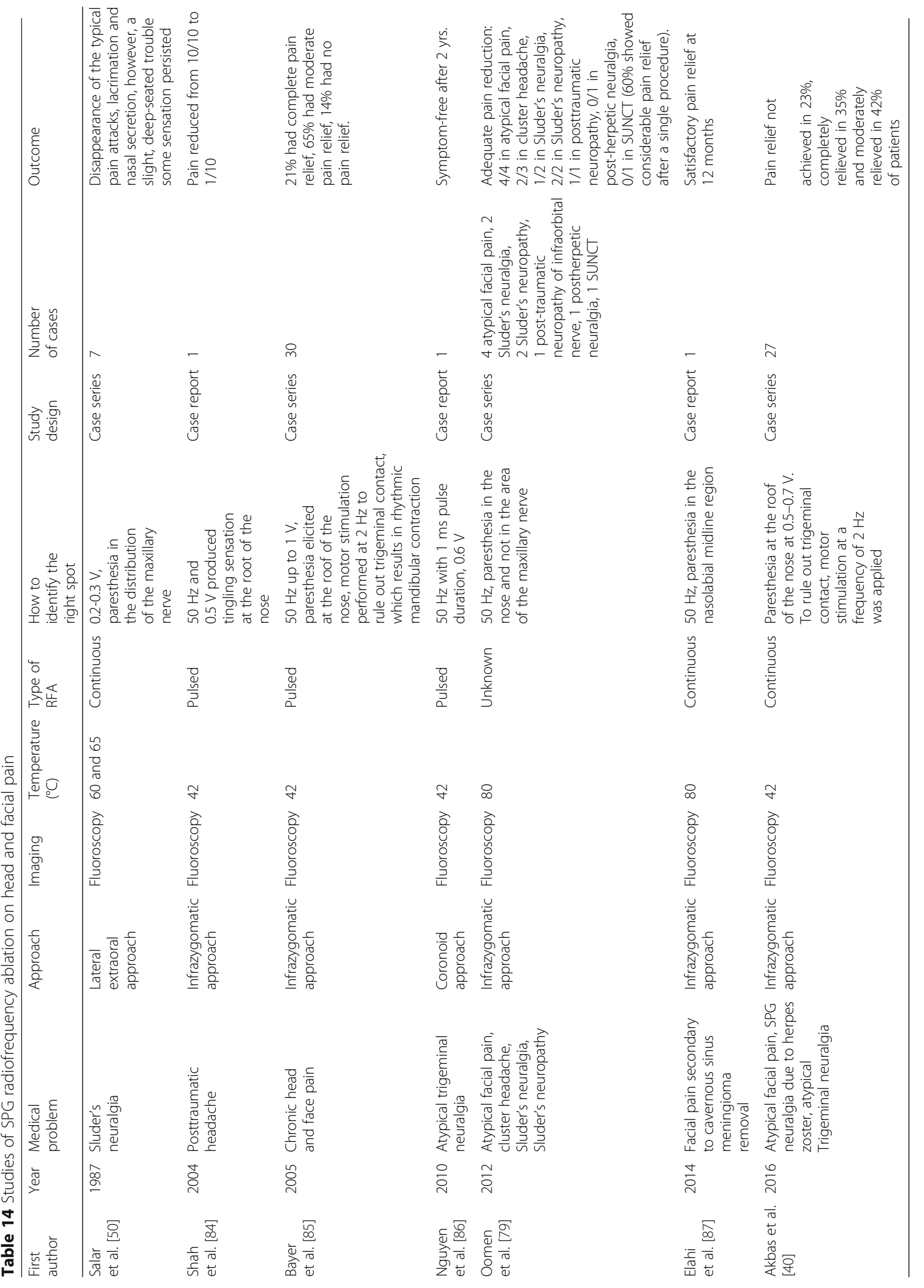




\section{Summary for SPG radiofrequency ablation}

Grade of recommendation is B for applying SPG radiofrequency ablation to intractable cluster headache. The protocol used in the cohort study took infrazygomatic approach under fluoroscopy and two radiofrequency ablations were carried out at $80{ }^{\circ} \mathrm{C}$ for $60 \mathrm{~s}$. However, there is not yet a randomized-controlled study to test its efficacy. Grade of recommendation is $\mathrm{C}$ for other head and facial pain, including Sluder's neuralgia, posttraumatic headache, atypical trigeminal neuralgia, atypical facial pain, chronic facial pain secondary to cavernous sinus meningioma, trigeminal neuralgia and SPG neuralgia due to herpes zoster.

\section{Sphenopalatine ganglion neurostimulation}

Eight studies were included for SPG neurostimulation. There was one randomized-controlled study with two long-term follow-ups of the same study and five case report/case series on sphenopalatine ganglion neurostimulation (Table 15).

\section{Cluster headache}

There was one randomized-controlled study with two long-term follow-ups of the same study, and two case reports/series on cluster headache. Schoenen et al. [41] reported a randomized-controlled trial using SPG neurostimulator for patients with refractory cluster headaches. Twenty-eight patients underwent SPG stimulator implantation and stimulations were applied at the onset of cluster headache. The study employed a protocol that randomly inserted a placebo when treatment was initiated by the patient for a cluster headache attack. Three settings were delivered in a randomized fashion (1:1:1): full stimulation (i.e. customized stimulation parameters established during the therapy titration period), subperception stimulation, and sham stimulation. A total of 566 cluster headaches were treated, and pain relief was achieved in $67.1 \%$ of patients receiving full stimulation compared to $7.4 \%$ receiving sham treatment $(P<0.0001)$. Pain relief using sub-perception stimulation was not significantly different from sham stimulation $(P=0.96)$. Acute rescue medication was used in $31 \%$ of cluster headache attacks in patients receiving full stimulation, compared to $77.4 \%$ treated with sham stimulation $(\mathrm{P}<0.0001)$ and $78.4 \%$ with sub-perception stimulation $(\mathrm{P}<0.0001)$. In terms of side effect, most patients $(81 \%)$ experienced transient, mild to moderate loss of sensation within distinct maxillary nerve regions; $65 \%$ of events resolved within 3 months. Jurgens et al. [42] reported a cohort study from the subjects who volunteered to be followed for 24 months from the study by Schoenen et al. In this study, $61 \%$ of patients were either acute responder $(>50 \%$ relief from moderate or greater pain) or frequency responder $(>50 \%$ in attack frequency) at 24 months.
Barloese et al. [9] analyzed participants who experienced remission from the same dataset. 30\% of participants were found to have at least 1 episode of complete attack remission in the 24-month period. Ansarinia et al. [44] reported a case series of 6 patients. Out of the 18 attacks recorded, there were 11 attacks receiving complete relief from the stimulations, 3 getting partial relief and 4 without relief.

With the positive randomized-controlled trial, the grade of recommendation is B for using SPG neurostimulation on cluster headache. Given the positive effect from these studies, further trials are encouraged.

\section{Migraine headache}

There was one case series of 11 cases on SPG neurostimulation in acutely treating intractable migraine headaches [45]. In this study, 11 patients with a history of migraine headache for a mean of 20 years were studied. Spontaneous and induced migraine headaches were acutely treated with SPG neurostimulation. Out of the 11 treated, two patients were pain-free, three had some pain reduction, while five had no response. Because of the largely negative response, there is currently not enough evidence for treating intractable migraine with SPG neurostimulation.

\section{Other head and facial pain}

There was one case series and one case report on other types of head and facial pain. William et al. [46] reported a case series on idiopathic facial pain, supraorbital neuropathy, hemicrania continua, facial anesthesia dolorosa and occipital neuropathy. SPG neurostimulation was combined with trigeminal or peripheral stimulation. 80\% of the patients reviewed reported sustained relief in facial pain. It is unclear whether SPG stimulation alone would provide the same relief in these cases. Elahi et al. [47] reported a single case of SPG neurostimulation for idiopathic facial pain with good success.

Given the sparse literature, the grade of recommendation is C for SPG neurostimulation in idiopathic facial pain and D for SPG stimulation combined with trigeminal/peripheral stimulation in supraorbital neuropathy, hemicrania continua, facial anesthesia dolorosa and occipital neuropathy.

\section{Summary for SPG neurostimulation}

Grade of recommendation is B for applying SPG neurostimulation to cluster headache and $\mathrm{C}$ for idiopathic facial pain. There may be a role of combined SPG and trigeminal or peripheral neurostimulation in isolated cases. Due to its invasive nature, SPG neurostimulation warrants further investigations with more high quality, large-scale studies. 


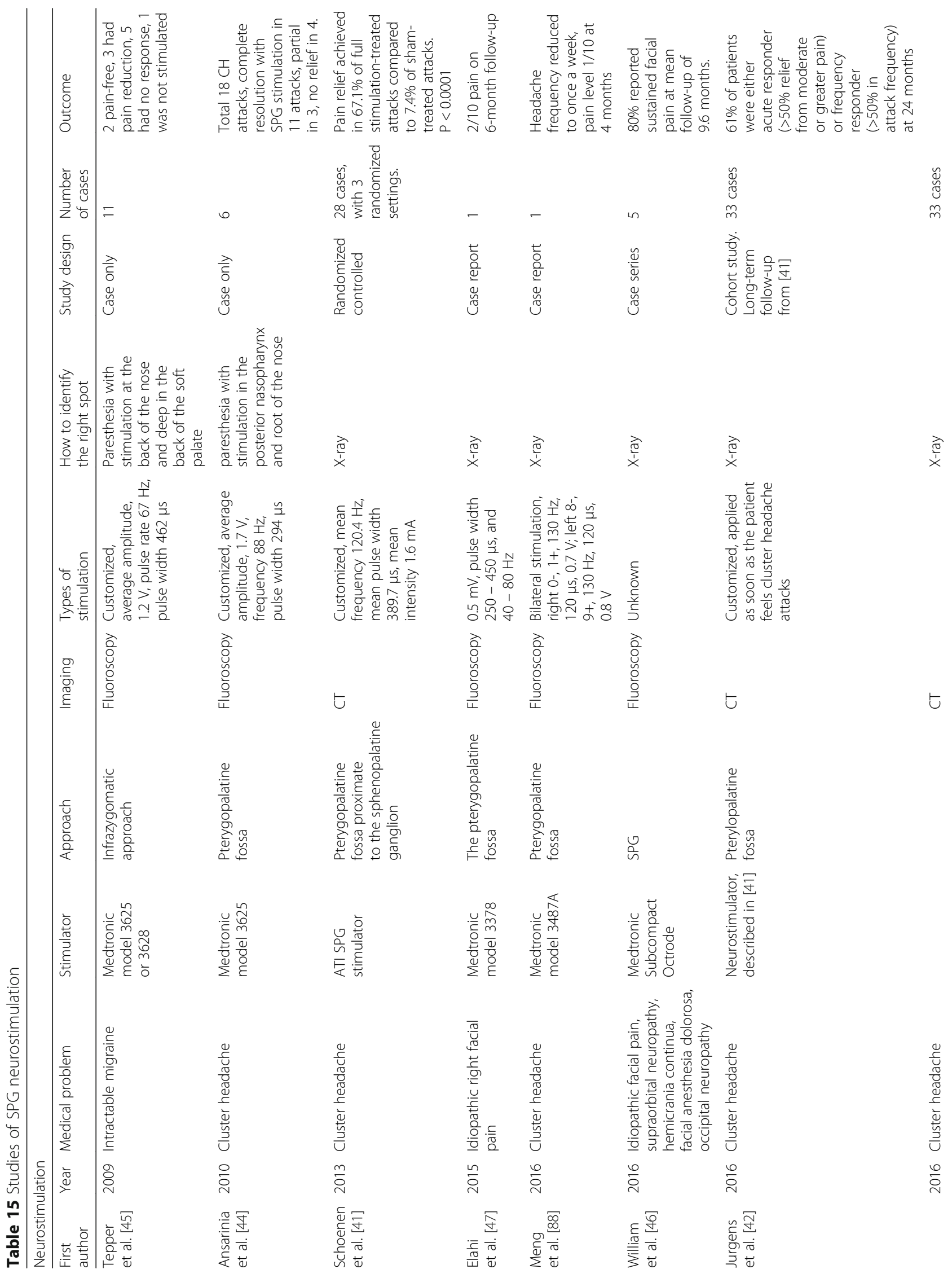




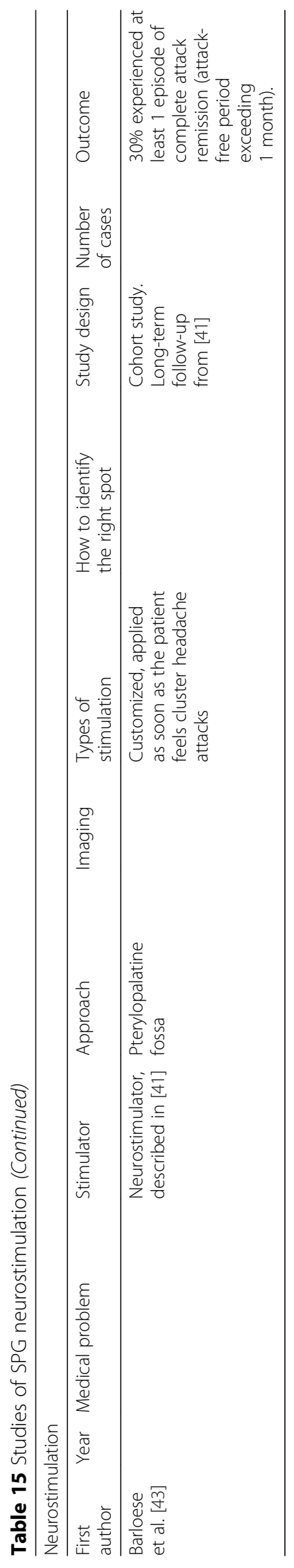




\section{Discussion}

\section{Sphenopalatine ganglion block}

Sphenopalatine ganglion block has been used for over a century. In 1908, Sluder first proposed that inflammation in the posterior ethmoid and sphenoid sinuses may be involved in unilateral facial pain associated with tearing, congestion and rhinorrhea. He also claimed to have successfully treated facial neuralgia, asthma, earache and lower-half headache. Over time, the term Sluder's neuralgia has varied definitions across the medical literature. Its characteristics mostly resemble cluster headache and it has been suggested that the term Sluder's neuralgia be discarded [48]. However, an analysis suggested that cluster headache and Sluder's neuralgia may be two different entities [49]. This review kept Sluder's neuralgia and cluster headaches as two distinct type of headaches because of the differences. Since Sluder's first publication, SPG block has been reported to be used successfully in treating multiple pain syndromes, including cluster headaches, trigeminal neuralgia, migraine, postherpetic neuralgia and atypical facial pain. It was also used for treating intractable cancer pain of the head and face as well as facial pain management after endoscopic sinus surgery. However, for most pain syndromes the evidence for using SPG nerve block remains at case report and case series level. There were a few small yet positive randomized-controlled studies in nitroglycerin-induced cluster headache, second-division trigeminal neuralgia, migraine, reducing the pain associated with nasal packing removal after nasal operation and for reducing the needs of analgesics after endoscopic sinus surgery. It should be emphasized that the evidence for treating these conditions with SPG block is based on very few small studies. The exception lies in reducing the needs of analgesics after endoscopic sinus surgery, which is backed by five randomized-controlled studies. It should be also noted that long-term treatment may not be beneficial, as demonstrated by the chronic repetitive block study in migraine by Cady et al. [16]. When SPG block is offered as a treatment option, patients should be informed of such caveats.

\section{Blocking strategies}

Several techniques exist for SPG blockade. Four types of applications exist: cotton-tip applicator, Tx360 device, nasal spray and needle injections. Three main types of approaches exist: transnasal, transoral and infrazygomatic approaches. Cotton-tip applicator, Tx360 device and nasal spray can only be applied through the transnasal approach. Needle injection, on the other hand, can be performed in any approach. Applied local anesthetics included lidocaine, bupivacaine, ropivacaine, levobupivacine, mepivacaine, novocaine, nupercaine, pontocaine, monocaine, tetracaine, and prilocaine, with varying concentrations, but lidocaine and bupivacaine were by far the most common. Other medications include cocaine, ethanol and phenol. Co-medications included epinephrine, triamcinolone and dexamethasone. Some studies used fluoroscopy or CT to guide needle placement. Unfortunately, there are no head-to-head trials comparing the efficacy among different blocking strategies. The recommendations made in this article are based on strategies used in the positive controlled studies.

\section{Side effects}

Side effects from SPG blockade is typically local. Potential side effects are numbness and stinging at the root of the nose and palate, numbness or lacrimation of ipsilateral eye, and bitter taste and numbness of the throat. With needle injection techniques, there is also the risk of bleeding, infection and epistaxis.

\section{Sphenopalatine ganglion radiofrequency ablation}

The use of radiofrequency on sphenopalatine ganglion was first reported by Salar et al. [50] for treating Sluder's neuralgia. Since the first report, there were multiple case reports on using SPG radiofrequency ablation in treating head and facial pain. About half of the reports focused on treating cluster headaches, but it has also been successfully used on patients with post-traumatic headache, atypical trigeminal neuralgia and anesthesia dolorosa after cavernous meningioma surgery. However, most of the literature today remains at the case report and case series level. There was only one small prospective cohort study on the effectiveness of SPG radiofrequency ablation. Well-controlled studies are yet to be performed to confirm the validity of this therapeutic modality in treating headache and facial pain.

Compared to the short-lived effect of SPG block, SPG radiofrequency ablation tend to be long lasting. Narouze et al. [38] reported statistically improved attack intensity, frequency and pain disability index up to 18 months in patients who underwent SPG radiofrequency ablation. As a comparison, Costa et al. [6] only reported shorter cluster headache duration with SPG block, and Cady et al. reported only up to $24 \mathrm{~h}$ of relief in chronic migraine [15] while no difference was found at 1 and 6 months with repetitive SPG block [16].

\section{Ablation strategies}

Most radiofrequency ablation of SPG were carried out with the infrazygomatic approach. The most commonly used temperature is $80{ }^{\circ} \mathrm{C}$ for thermal ablation, and $42^{\circ}$ $\mathrm{C}$ for pulsed ablation. There is unfortunately no headto-head comparison between the two types of ablations. All studies confirmed the position of RF cannula/probe by applying low voltage sensory stimulation (between 0.2-0.1 V) while patients felt paresthesia or tingling 
sensation at the root of the nose. The only study with evidence level above case series was a cohort study on patients with chronic cluster headache [38]. In this positive study, the authors applied 2 rounds of thermal ablation at $80{ }^{\circ} \mathrm{C}$ for $60 \mathrm{~s}$ each. Pre- and post-ablation medications were also given (pre: $0.5 \mathrm{ml}$ of $2 \%$ lidocaine; post: $0.5 \mathrm{ml}$ of $0.5 \%$ bupivacaine and $5 \mathrm{mg}$ of triamcinolone).

\section{Side effects}

Based on the study by Narouze et al. [38], about 50\% (7/ 15) reported temporary paresthesias in the upper gums and cheek that lasted for 3-6 weeks with complete resolution. Rare permanent small zone of hypoesthesia over the cheek could also happen. In the large case series by Sanders et al. [39], of the 66 treated patients, eight patients experienced temporary postoperative epistaxis and 11 patients exhibited cheek hematomas. A partial radiofrequency lesion of the maxillary nerve was inadvertently made in four patients. Nine patients complained of hypoesthesia of the palate, which disappeared in all patients within 3 months.

\section{Sphenopalatine ganglion neurostimulation}

Neurostimulation has emerged in recent years as a potential therapeutic modality for headaches and facial pain. Even though number of studies on SPG neurostimulation has not been abundant, the overall quality of the studies has been high. The study by Shoenen et al. [41] was the only randomized-controlled study in using SPG neurostimulation to treat chronic cluster headache. Despite the small number of participants, the effectiveness is demonstrated by the large effect size and highly significant $P$ value. The two long-term follow-up articles continued to support the effectiveness of such intervention $[42,43]$. These three studies combined is the strongest piece evidence to date, suggesting that SPG neurostimulation is effective in treating cluster headache. There were other isolated case reports on the successful application of SPG neurostimulation to other pain syndromes, but higher level of evidence is lacking.

\section{Stimulation strategies}

Stimulation settings vary widely across study subjects, stimulator models and studies. In the controlled study by Schoenen et al. [41], the mean frequency was $120.4 \pm$ $15.5 \mathrm{~Hz}$, mean pulse width $389.7 \pm 75.4 \mu$ s with mean intensity $1.6 \pm 0.8 \mathrm{~mA}$ during full stimulation. These numbers are for references only, and the stimulation setting should be individualized based on responses.

\section{Side effects}

In Schoenen's controlled study [41], the most common acute side effects are sensory disturbances (81\%), pain (38\%), swelling (22\%). Other side effects included tooth pain $(16 \%)$, trismus (16\%), headache (9\%), dry eye (9\%), and hematoma (9\%). Across all 32 patients, five deviceor procedure-related serious adverse events occurred. The most common serious adverse events are due to erroneous lead placements and lead migration to adjacent nerves.

\section{Limitations}

There are several limitations in our review. Firstly, articles could have been missed because only Pubmed, CENTRAL and Google Scholar were used. Second, most of the studies included in this review were case studies and case reports. By nature of these kinds of studies, publication bias will be skewed toward positive outcomes. Thirdly, due to the paucity of controlled studies, meta-analysis could not be adequately performed to create a quantitative analysis. Despite these limitations, this study was the first to systematically summarize SPG interventions. As more controlled studies become available, meta-analysis will be possible and thus providing better level of evidence in this developing field.

\section{Conclusions}

SPG has been the target for treating pain syndrome in the head and face for over a hundred years. The strongest evidence lies in using SPG block, radiofrequency ablation and neurostimulation on cluster headache. Sphenopalatine ganglion block also has good evidence in treating trigeminal neuralgia, migraines, reducing the needs of analgesics after endoscopic sinus surgery and reducing pain associated with nasal packing removal after nasal operations. Large-scale, double-blinded, randomized-controlled studies are warranted in establishing these techniques in treating cluster headache and other head and facial pain.

\section{Additional file}

Additional file 1: PRISMA checklist. (DOC $64 \mathrm{~kb}$ )

Abbreviations

SPG: Sphenopalatine ganglion; TAC: Trigeminal autonomic cephalalgia

\section{Acknowledgements}

Not applicable.

\section{Funding}

No funding was received for this manuscript.

Availability of data and materials

Not applicable.

Authors' contributions

KWDH designed the study, managed the literature searches and summaries of previous related work and wrote the first draft of the manuscript. RP and SK critically reviewed the study manuscript and provided revisions for intellectual content. All authors read and approved the final manuscript. 


\section{Authors' information}

Not applicable.

\section{Ethics approval and consent to participate}

Not applicable.

\section{Consent for publication}

Not applicable.

\section{Competing interests}

The authors declare that they have no competing interests.

\section{Publisher's Note}

Springer Nature remains neutral with regard to jurisdictional claims in published maps and institutional affiliations.

\section{Author details}

'Department of Neurology, University of Florida, PO Box 100236,1149 Newell Drive, Room L3-100, Gainesville, FL 32611, USA. ²Department of Anesthesiology, University of Florida, 1600 SW Archer Road, PO Box 100254 Gainesville, FL 32610, USA

Received: 5 October 2017 Accepted: 24 November 2017

Published online: 28 December 2017

\section{References}

1. Piagkou M, Demesticha T, Troupis T, Vlasis K, Skandalakis P, Makri A, Mazarakis A, Lappas D, Piagkos G, Johnson EO (2012) The pterygopalatine ganglion and its role in various pain syndromes: from anatomy to clinical practice. Pain Pract 12(5):399-412. https://doi.org/10.1111/j.1533-2500.2011. 00507.x

2. Oluigbo CO, Makonnen G, Narouze S, Rezai AR (2011) Sphenopalatine ganglion interventions: technical aspects and application. Prog Neurol Surg 24:171-179. https://doi.org/10.1159/000323049

3. Scudds RA, Janzen V, Delaney G, Heck C, McCain GA, Russell AL, Teasell RW, Varkey G, Woodbury MG (1995) The use of topical 4\% lidocaine in sphenopalatine ganglion blocks for the treatment of chronic muscle pain syndromes: a randomized, controlled trial. Pain 62(1):69-77

4. Kent S, Mehaffey G (2015) Transnasal sphenopalatine ganglion block for the treatment of postdural puncture headache in the ED. Am J Emerg Med 33(11):1714.e1711-1714.e1712. https://doi.org/10.1016/j.ajem.2015.03.024

5. Higgins JP, Altman DG, Gøtzsche PC, Jüni P, Moher D, Oxman AD, Savovic J, Schulz KF, Weeks L, Sterne JA, Group CBM, Group CSM (2011) The Cochrane Collaboration's tool for assessing risk of bias in randomised trials. BMJ 343: d5928

6. Costa A, Pucci E, Antonaci F, Sances G, Granella F, Broich G, Nappi G (2000) The effect of intranasal cocaine and lidocaine on nitroglycerin-induced attacks in cluster headache. Cephalalgia 20(2):85-91

7. Barre F (1982) Cocaine as an abortive agent in cluster headache. Headache: $J$ Head Face Pain 22(2):69-73

8. Kittrelle JP, Grouse DS, Seybold ME (1985) Cluster headache: local anesthetic abortive agents. Arch Neurol 42(5):496

9. Felisati G, Arnone F, Lozza P, Leone M, Curone M, Bussone G (2006) Sphenopalatine endoscopic ganglion block: a revision of a traditional technique for cluster headache. Laryngoscope 116(8):1447-1450

10. Pipolo C, Bussone G, Leone M, Lozza P, Felisati G (2010) Sphenopalatine endoscopic ganglion block in cluster headache: a reevaluation of the procedure after 5 years. Neurol Sci 31(Suppl 1):S197-S199. https://doi.org/ 10.1007/s10072-010-0325-2

11. Kanai A, Suzuki A, Kobayashi M, Hoka S (2006) Intranasal lidocaine 8\% spray for second-division trigeminal neuralgia. Br J Anaesth 97(4):559-563

12. Peterson JN, Schames J, Schames M, King E (1995) Sphenopalatine ganglion block: a safe and easy method for the management of orofacial pain. Cranio 13(3):177-181

13. Manahan AP, Malesker MA, Malone PM (1996) Sphenopalatine ganglion block relieves symptoms of trigeminal neuralgia: a case report. Nebr Med $J$ 81(9):306-309

14. Candido KD, Massey ST, Sauer R, Darabad RR, Knezevic NN (2013) A novel revision to the classical transnasal topical sphenopalatine ganglion block for the treatment of headache and facial pain. Pain Physician 16(6):E769-E778
15. Cady R, Saper J, Dexter K, Manley HR (2015a) A double-blind, placebocontrolled study of repetitive transnasal sphenopalatine ganglion blockade with $\mathrm{t} \times 360\left({ }^{\circledR}\right)$ as acute treatment for chronic migraine. Headache 55(1):101116. https://doi.org/10.1111/head.12458

16. Cady RK, Saper J, Dexter K, Cady RJ, Manley HR (2015b) Long-term efficacy of a double-blind, placebo-controlled, randomized study for repetitive sphenopalatine blockade with bupivacaine vs. saline with the Tx360 device for treatment of chronic migraine. Headache 55(4):529-542. https://doi.org/ 10.1111/head. 12546

17. Cho DY, Drover DR, Nekhendzy V, Butwick AJ, Collins J, Hwang PH (2011) The effectiveness of preemptive sphenopalatine ganglion block on postoperative pain and functional outcomes after functional endoscopic sinus surgery. Int Forum Allergy Rhinol 1(3):212-218. https://doi.org/10.1002/ alr.20040

18. Ahmed H, Abu-Zaid E (2007) Role of intraoperative endoscopic sphenopalatine ganglion block in sinonasal surgery. J Med Sci 7:1297-1303

19. Al-Qudah M (2016) Endoscopic sphenopalatine ganglion blockade efficacy in pain control after endoscopic sinus surgery. Int Forum Allergy Rhinol 6(3): 334-338. https://doi.org/10.1002/alr.21644

20. Ali AR, Sakr SA, Rahman ASM (2010) Bilateral sphenopalatine ganglion block as adjuvant to general anaesthesia during endoscopic trans-nasal resection of pituitary adenoma. Egypt J Anaesth 26(4):273-280

21. DeMaria S, Govindaraj S, Chinosorvatana N, Kang S, Levine Al (2012) Bilateral sphenopalatine ganglion blockade improves postoperative analgesia after endoscopic sinus surgery. Am J Rhinol Allergy 26(1):e23-e27. https://doi. org/10.2500/ajra.2012.26.3709

22. Kesimci E, Öztürk L, Bercin S, Kırış M, Eldem A, Kanbak O (2012) Role of sphenopalatine ganglion block for postoperative analgesia after functional endoscopic sinus surgery. Eur Arch Otorhinolaryngol 269(1):165-169. https://doi.org/10.1007/s00405-011-1702-z

23. Hwang JH, Liu CM, Liu TC, Hsu MC (2003) Sphenopalatine ganglion block before removal of nasal packing. Laryngoscope 113(8):1423-1424. https:// doi.org/10.1097/00005537-200308000-00030

24. Robiony M, Demitri V, Costa F, Politi M, Cugini U (1998) Truncal anaesthesia of the maxillary nerve for outpatient surgically assisted rapid maxillary expansion. Br J Oral Maxillofac Surg 36(5):389-391

25. Varghese BT, Koshy RC (2001) Endoscopic transnasal neurolytic sphenopalatine ganglion block for head and neck cancer pain. J Laryngol Otol 115(5):385-387

26. Prasanna A, Murthy PS (1993a) Combined stellate ganglion and sphenopalatine ganglion block in acute herpes infection. Clin J Pain 9(2):135-137

27. Saberski L, Ahmad M, Wiske P (1999) Sphenopalatine ganglion block for treatment of sinus arrest in postherpetic neuralgia. Headache 39(1):42-44. https://doi.org/10.1046/j.1526-4610.1999.3901042.x

28. Amster J (1948) Sphenopalatine ganglion block for the relief of painful vascular and muscular spasm with special reference to lumbosacral pain. N Y State J Med 48(22):2475

29. Ruskin SL (1946) The control of muscle spasm and arthritic pain through sympathetic block at the nasal ganglion and the use of the adenylic nucleotide. Am J Dig Dis 13(10):311-320

30. Janzen VD, Scudds R (1997) Sphenopalatine blocks in the treatment of pain in fibromyalgia and myofascial pain syndrome. Laryngoscope 107(10):1420-1422

31. Ferrante FM, Kaufman AG, Dunbar SA, Cain CF, Cherukuri S (1998) Sphenopalatine ganglion block for the treatment of myofascial pain of the head, neck, and shoulders. Reg Anesth Pain Med 23(1):30-36

32. Berger JJ, Pyles ST, Saga-Rumley SA (1986) Does topical anesthesia of the sphenopalatine ganglion with cocaine or lidocaine relieve low back pain? Anesth Analg 65(6):700-702

33. Cohen S, Sakr A, Katyal S, Chopra D (2009) Sphenopalatine ganglion block for postdural puncture headache. Anaesthesia 64(5):574-575. https://doi. org/10.1111/j.1365-2044.2009.05925.x

34. Schaffer JT, Hunter BR, Ball KM, Weaver CS (2015) Noninvasive sphenopalatine ganglion block for acute headache in the emergency department: a randomized placebo-controlled trial. Ann Emerg Med 65(5): 503-510. https://doi.org/10.1016/j.annemergmed.2014.12.012

35. Rodman R, Dutton J (2012) Endoscopic neural blockade for rhinogenic headache and facial pain: 2011 update. Int Forum Allergy Rhinol 2(4):325330. https://doi.org/10.1002/alr.21035

36. Henneberger JT, Menk EJ, Middaugh RE, Finstuen K (1988) Sphenopalatine ganglion blocks for the treatment of nicotine addiction. South Med J 81(7): 832-836 
37. Silverman DG, Spencer RF, Kitahata LM, O'Connor TZ (1993) Lack of effect of sphenopalatine ganglion block with intranasal lidocaine on submaximal effort tourniquet test pain. Reg Anesth 18(6):356-360

38. Narouze S, Kapural L, Casanova J, Mekhail N (2009) Sphenopalatine ganglion radiofrequency ablation for the management of chronic cluster headache. Headache: J Head Face Pain 49(4):571-577

39. Sanders M, Zuurmond WW (1997) Efficacy of sphenopalatine ganglion blockade in 66 patients suffering from cluster headache: a 12- to 70-month follow-up evaluation. J Neurosurg 87(6):876-880. https://doi.org/10.3171/jns.1997.87.6.0876

40. Akbas M, Gunduz E, Sanli S, Yegin A (2016) Sphenopalatine ganglion pulsed radiofrequency treatment in patients suffering from chronic face and head pain. Braz J Anesthesiol 66(1):50-54. https://doi.org/10.1016/j.bjane.2014.06.001

41. Schoenen J, Jensen RH, Lantéri-Minet M, Láinez MJ, Gaul C, Goodman AM, Caparso A, May A (2013) Stimulation of the sphenopalatine ganglion (SPG) for cluster headache treatment. Pathway $\mathrm{CH}-1$ : a randomized, shamcontrolled study. Cephalalgia 0333102412473667

42. Jürgens TP, Barloese M, May A, Láinez JM, Schoenen J, Gaul C, Goodman AM, Caparso A, Jensen RH (2016) Long-term effectiveness of sphenopalatine ganglion stimulation for cluster headache. Cephalalgia. https://doi.org/10. $1177 / 0333102416649092$

43. Barloese MC, Jürgens TP, May A, Lainez JM, Schoenen J, Gaul C, Goodman AM, Caparso A, Jensen RH (2016) Cluster headache attack remission with sphenopalatine ganglion stimulation: experiences in chronic cluster headache patients through 24 months. J Headache Pain 17(1):67. https:// doi.org/10.1186/s10194-016-0658-1

44. Ansarinia M, Rezai A, Tepper SJ, Steiner CP, Stump J, Stanton-Hicks M, Machado A, Narouze S (2010) Electrical stimulation of sphenopalatine ganglion for acute treatment of cluster headaches. Headache: J Head Face Pain 50(7):1164-1174

45. Tepper SJ, Rezai A, Narouze S, Steiner C, Mohajer P, Ansarinia M (2009) Acute treatment of intractable migraine with sphenopalatine ganglion electrical stimulation. Headache 49(7):983-989. https://doi.org/10.1111/j. 1526-4610.2009.01451.x

46. William A, Azad TD, Brecher E, Cherry T, Bernstein I, Bruce DM, Rohrer S, Smith Z, William M, Sabelman E, Heit G, Pezeshkian P, Sedrak M (2016) Trigeminal and sphenopalatine ganglion stimulation for intractable craniofacial pain-case series and literature review. Acta Neurochir 158(3): 513-520. https://doi.org/10.1007/s00701-015-2695-y

47. Elahi F, Reddy CG (2015) Sphenopalatine ganglion electrical nerve stimulation implant for intractable facial pain. Pain Physician 18(3):E403-E409

48. Ahamed SH, Jones NS (2003) What is Sluder's neuralgia? J Laryngol Otol 117(6):437-443. https://doi.org/10.1258/002221503321892253

49. Oomen KP, van Wijck AJ, Hordijk GJ, de Ru JA (2010) Sluder's neuralgia: a trigeminal autonomic cephalalgia? Cephalalgia 30(3):360-364. https://doi. org/10.1111/j.1468-2982.2009.01919.x

50. Salar G, Ori C, lob I, Fiore D (1987) Percutaneous thermocoagulation for sphenopalatine ganglion neuralgia. Acta Neurochir 84(1):24-28

51. Slade SG, Linberg JV, Immediata AR (1986) Control of lacrimal secretion after sphenopalatine ganglion block. Ophthal Plast Reconstr Surg 2(2):65-70

52. Devoghel JC (1981) Cluster headache and sphenopalatine block. Acta Anaesthesiol Belg 32(1):101-107

53. Yang IY, Oraee S (2006) A novel approach to transnasal sphenopalatine ganglion injection. Pain Physician 9(2):131-134

54. Zarembinski C, Graff-Radford S (2014) An unusual challenge in performing sphenopalatine ganglion block with enlarged coronoid process: Jacob's disease. Pain Med 15(2):329-332. https://doi.org/10.1111/pme.12302

55. Kastler A, Cadel G, Comte A, Gory G, Piccand V, Tavernier L, Kastler B (2014) Alcohol percutaneous neurolysis of the sphenopalatine ganglion in the management of refractory cranio-facial pain. Neuroradiology 56(7):589-596. https://doi.org/10.1007/s00234-014-1354-y

56. Maizels M (1999) Intranasal lidocaine to prevent headache following migraine aura. Headache 39(6):439-442

57. Yarnitsky D, Goor-Aryeh I, Bajwa ZH, Ransil BI, Cutrer FM, Sottile A, Burstein R (2003) 2003 Wolff award: possible parasympathetic contributions to peripheral and central sensitization during migraine. Headache: J Head Face Pain 43(7):704-714

58. Prasanna A, Murthy PS (1993b) Sphenopalatine ganglion block and pain of cancer. J Pain Symptom Manag 8(3):125

59. Varghese BT, Koshy RC, Sebastian P, Joseph E (2002) Combined sphenopalatine ganglion and mandibular nerve, neurolytic block for pain due to advanced head and neck cancer. Palliat Med 16(5):447-448
60. Cohen S, Ramos D, Grubb W, Mellender S, Mohiuddin A, Chiricolo A (2014) Sphenopalatine ganglion block: a safer alternative to epidural blood patch for postdural puncture headache. Reg Anesth Pain Med 39(6):563. https:// doi.org/10.1097/AAP.0000000000000172

61. Cardoso JM, Sá M, Graça R, Reis H, Almeida L, Pinheiro C, Machado D (2017) Sphenopalatine ganglion block for postdural puncture headache in ambulatory setting. Rev Bras Anestesiol 67(3):311-313. https://doi.org/10. 1016/j.bjan.2017.02.003

62. Ruskin SL (1925) Contributions to the study of the spheno-palatine ganglion. Laryngoscope 35(2):87-108

63. Stechison MT, Brogan M (1994) Transfacial transpterygomaxillary access to foramen rotundum, sphenopalatine ganglion, and the maxillary nerve in the management of atypical facial pain. Skull Basenn 4(1):15-20

64. Saade E, Paige GB (1996) Patient-administered sphenopalatine ganglion block. Reg Anesth 21(1):68-70

65. Puig CM, Driscoll CL, Kern EB (1998) Sluder's sphenopalatine ganglion neuralgia-treatment with 88\% phenol. Am J Rhinol 12(2):113-118

66. Windsor RE, Jahnke S (2004) Sphenopalatine ganglion blockade: a review and proposed modification of the transnasal technique. Pain Physician 7(2):283-286

67. Obah C, Fine PG (2006) Intranasal sphenopalatine ganglion block: minimally invasive pharmacotherapy for refractory facial and headache pain. J Pain Palliat Care Pharmacother 20(3):57-59

68. Morelli N, Mancuso M, Felisati G, Lozza P, Maccari A, Cafforio G, Gori S, Murri L, Guidetti D (2010) Does sphenopalatine endoscopic ganglion block have an effect in paroxysmal hemicrania? A case report. Cephalalgia 30(3):365367. https://doi.org/10.1111/j.1468-2982.2009.01882.x

69. Grant GJ, Schechter D, Redai I, Lax J (2014) Transnasal topical sphenopalatine ganglion block to treat tension headache in a pregnant patient. Int J Obstet Anesth 23(3):292-293. https://doi.org/10.1016/j.joa. 2014.04.010

70. Androulakis XM, Krebs KA, Ashkenazi A (2016) Hemicrania continua may respond to repetitive sphenopalatine ganglion block: a case report Headache 56(3):573-579. https://doi.org/10.1111/head.12783

71. Malec-Milewska M, Horosz B, Kosson D, Sekowska A, Kucia H (2015) The effectiveness of neurolytic block of sphenopalatine ganglion using zygomatic approach for the management of trigeminal neuropathy. Neurol Neurochir Pol 49(6):389-394. https://doi.org/10.1016/j.pjnns.2015.08.010

72. Sussman WI, Mautner K, Mason RA, Bonecutter K, Shealy AK (2016) Sphenopalatine ganglion block for Management of Refractory Chronic Posttraumatic Headaches after a sport-related concussion. Clin J Sport Med. https://doi.org/10.1097/JSM.0000000000000325

73. Byrd H, Byrd W (1930) Sphenopalatine phenomena: present status of knowledge. Arch Intern Med 46(6):1026-1038

74. Sparer W (1935) Cessation of convulsive seizures following injection of alcohol into spheno-palatine ganglia. Three Cases The Laryngoscope 45(11): 886-890

75. Ruskin SL (1949) A newer concept of arthritis and the treatment of arthritic pain and deformity by sympathetic block at the sphenopalatien (nasal) ganglion and the use of the iron salt of the adenylic nucleotide. Am J Dig Dis 16(11):386-401

76. Quevedo JP, Purgavie K, Platt H, Strax TE (2005) Complex regional pain syndrome involving the lower extremity: a report of 2 cases of sphenopalatine block as a treatment option. Arch Phys Med Rehabil 86(2): 335-337. https://doi.org/10.1016/j.apmr.2004.04.033

77. Triantafyllidi H, Arvaniti C, Palaiodimos L, Vlachos S, Schoinas A, Batistaki C, Kostopanagiotou G, Lekakis J (2016) Infiltration of the sphenopalatine ganglion decreases blood pressure in newly diagnosed and never treated patients with essential hypertension. Int J Cardiol 223:345-351. https://doi. org/10.1016/.j.jcard.2016.08.230

78. Chua NH, Vissers KC, Wilder-Smith OH (2011) Quantitative sensory testing may predict response to sphenopalatine ganglion pulsed radiofrequency treatment in cluster headaches: a case series. Pain Pract 11(5):439-445. https://doi.org/10.1111/j.1533-2500.2010.00445.x

79. Oomen KP, van Wijck AJ, Hordijk GJ, de Ru JA (2012) Effects of radiofrequency thermocoagulation of the sphenopalatine ganglion on headache and facial pain: correlation with diagnosis. J Orofac Pain 26(1):59-64

80. Fang L, Jingjing L, Ying S, Lan M, Tao W, Nan J (2016) Computerized tomography-guided sphenopalatine ganglion pulsed radiofrequency treatment in 16 patients with refractory cluster headaches: twelve- to 30month follow-up evaluations. Cephalalgia 36(2):106-112. https://doi.org/10. $1177 / 0333102415580113$ 
81. Bendersky DC, Hem SM, Yampolsky CG (2015) Unsuccessful pulsed radiofrequency of the sphenopalatine ganglion in patients with chronic cluster headache and subsequent successful thermocoagulation. Pain Pract 15(5):E40-E45. https://doi.org/10.1111/papr.12288

82. Dharmavaram SKA, Palanisamy V, Raju SK (2016) Conventiona radiofrequency ablation of sphenopalatine ganglion for the treatment of cluster headache. Indian J Pain 30

83. Loomba V, Upadhyay A, Kaveeshvar H (2016) Radiofrequency ablation of the Sphenopalatine ganglion using cone beam computed tomography for intractable cluster headache. Pain Physician 19(7):E1093-E1096

84. Shah RV, Racz GB (2004) Long-term relief of posttraumatic headache by sphenopalatine ganglion pulsed radiofrequency lesioning: a case report. Arch Phys Med Rehabil 85(6):1013-1016

85. Bayer E, Racz GB, Miles D, Heavner J (2005) Sphenopalatine ganglion pulsed radiofrequency treatment in 30 patients suffering from chronic face and head pain. Pain Pract 5(3):223-227

86. Nguyen M, Wilkes D (2010) Pulsed radiofrequency V2 treatment and intranasal sphenopalatine ganglion block: a combination therapy for atypical trigeminal neuralgia. Pain Pract 10(4):370-374

87. Elahi F, Ho KWD (2014) Successful Management of Refractory headache and facial pain due to cavernous sinus Meningioma with Sphenopalatine ganglion radiofrequency. In: Case report in neurological medicine

88. Meng DW, Zhang JG, Zheng Z, Wang X, Luo F, Zhang K (2016) Chronic bilateral Sphenopalatine ganglion stimulation for intractable bilateral chronic cluster headache: a case report. Pain Physician 19(4):E637-E642

\section{Submit your manuscript to a SpringerOpen ${ }^{\circ}$ journal and benefit from:}

- Convenient online submission

- Rigorous peer review

- Open access: articles freely available online

- High visibility within the field

- Retaining the copyright to your article

Submit your next manuscript at $>$ springeropen.com 